\title{
1 Dissolved organic matter sources in large Arctic rivers
}

2 R.M.W. Amon ${ }^{\mathrm{a}, \mathrm{b}, *}$, A.J. Rinehart ${ }^{\mathrm{b} \dagger}$, S. Duan ${ }^{\mathrm{a}}$, P. Louchouarn ${ }^{\mathrm{a}, \mathrm{b}}$, A. Prokushkin ${ }^{\mathrm{c}}$, G. Guggenberger ${ }^{\mathrm{d}}$, D.

3 Bauch $^{\mathrm{e}}$, C. Stedmon ${ }^{\mathrm{f}}$, P.A. Raymond ${ }^{\mathrm{g}}$, R.M. Holmes ${ }^{\mathrm{h}}$, J.W. McClelland ${ }^{\mathrm{i}}$, B.J. Peterson ${ }^{\mathrm{j}}$, S.A.Walker ${ }^{\mathrm{b}}$,

$4 \quad$ A.V. Zhulidov ${ }^{k}$

$5 \quad{ }^{\mathrm{a}}$ Department of Marine Sciences, Texas A\&M University at Galveston, Galveston, USA.

$6 \quad{ }^{b}$ Department of Oceanography, Texas A\&M University, College Station, USA.

$7 \quad$ V.N. Sukachev Institute of Forest SB RAS, Akademgorodok, Krasnoyarsk, Russia

8 Institut für Bodenkunde, Leibniz-Universität Hannover, Hannover, Germany

$9 \quad{ }^{\mathrm{e}}$ Leibniz Institute of Marine Sciences, University of Kiel (IFM-GEOMAR), Kiel, Germany

10 f Department of Marine Ecology, National Environmental Research Institute,

11 University of Aarhus, Roskilde, Denmark.

$12{ }^{\mathrm{g}}$ Yale School of Forestry and Environmental Studies, Yale University, Connecticut, USA

$13{ }^{\mathrm{h}}$ The Woods Hole Research Center, Woods Hole, Massachusetts USA

$14{ }^{\mathrm{i}}$ Marine Science Institute, University of Texas at Austin, Port Aransas, Texas USA

$15{ }^{\mathrm{j}}$ Marine Biological Laboratory, Woods Hole, Massachusetts USA

$16{ }^{\mathrm{k}}$ South Russia Centre for Preparation and Implementation of International Projects, Rostov-on-Don,

17 Russia

$18{ }^{\dagger}$ Current address: Institute of Arctic Biology, University of Alaska Fairbanks, Fairbanks, AK, USA.

$19{ }^{\ddagger}$ Current address: Earth System Science Interdisciplinary Center, University of Maryland, College Park, 20 MD, USA 
27 We dedicate this paper to the memory of Patrick L. Parker, a trailblazer for organic and stable

28 isotope geochemistry. He has influenced many discoveries and their makers that have ultimately

29 facilitated this paper. This work was supported by the National Science Foundation through

30 grants OPP-0229302, ARC-0425582, ARC-0713991. Additional support was provided by Texas

31 A\&M University at Galveston, the U. S. Geological Survey (Yukon River), the Carlsberg

32 Foundation and the Department of Indian and Northern Affairs (Mackenzie River). We thank

33 Tim Brabets, Ludmila Boeva, Ludmila Kosmenko, Charlie Couvillon, Elena Dunaeva, Martin

34 Kelly, Dave Milburn, Yana Adreeva, Anna Suslova, and Mikhail Suslov for assistance with

35 sample collection, and Alexander Shiklomanov for additional discharge data for the Kolyma

36 River. Discussions with John Gibson and Greg Fiske improved our understanding of

37 groundwater hydrology and watershed vegetation data, respectively, and are highly appreciated. 
Abstract

50 The biomarker composition of dissolved organic carbon (DOC) of the six largest Arctic rivers

51 was studied between 2003 and 2007 as part of the PARTNERS Project. Samples were collected

52 over seasonal cycles relatively close to the river mouths. Here we report the lignin phenol and p-

53 hydroxybenzene composition of Arctic river DOC in order to identify major sources of carbon.

54 Arctic river DOC represents an important carbon conduit linking the large pools of organic

55 carbon in the Arctic/Subarctic watersheds to the Arctic Ocean. Most of the annual lignin

56 discharge $(>75 \%)$ occurs during the two month of spring freshet with extremely high lignin

57 concentrations and a lignin phenol composition indicative of fresh vegetation from boreal

58 forests. The three large Siberian rivers, Lena, Yenisei, and Ob, which also have the highest

59 proportion of forests within their watersheds, contribute about $90 \%$ of the total lignin discharge

60 to the Arctic Ocean. The composition of river DOC is also characterized by elevated levels of p-

61 hydroxybenzenes, particularly during the low flow season, which indicates a larger contribution

62 from mosses and peat bogs. The lignin composition was strongly related to the average ${ }^{14} \mathrm{C}$-age

63 of DOC supporting the abundance of young, boreal-vegetation-derived leachates during spring

64 flood, and older, soil-, peat-, and wetland-derived DOC during groundwater dominated low flow

65 conditions, particularly in the $\mathrm{Ob}$ and Yukon Rivers. We observed significant differences in

66 DOC concentration and composition between the rivers over the seasonal cycles with the

67 Mackenzie River being the most unique, the Lena River being similar to the Yenisei, and the

68 Yukon being most similar to the $\mathrm{Ob}$. The observed relationship between the lignin phenol

69 composition and watershed characteristics suggests that DOC discharge from these rivers could

70 increase in a warmer climate under otherwise undisturbed conditions. 


\section{1. INTRODUCTION}

73 The watersheds of the six largest Arctic rivers (Ob, Yenisei, Lena, Kolyma, Yukon, and

74 Mackenzie) cover more than $10 \times 10^{6} \mathrm{~km}^{2}$ of surface area (larger than Canada) including extended

75 boreal forests, tundra, and wetlands. Approximately $76 \%$ of the combined watershed area is

76 located in Eurasia (Zhulidov et al., 1997). Within these large watersheds lies an immense carbon

77 reservoir, including biomass organic carbon in vegetation, soil organic carbon, and methane

78 hydrates. A large portion of the soil organic carbon is trapped in permafrost soils with $\sim 54 \%$ of

79 this designated as continuous permafrost (Tarnocai et al., 2009). Among these large carbon

80 pools, soil organic carbon is quantitatively the most important with $1400-1850 \mathrm{PgC}$, followed by

81 60-70 Pg biomass carbon, and 2-65 PgC as land-based methane hydrates (Tarnocai et al., 2009).

82 The soil organic carbon in these watersheds represents roughly $50 \%$ of the global soil organic

83 matter with $67 \%$ of it located in the Eurasian watersheds (Tarnocai et al., 2009). Biomass carbon

84 in Arctic watersheds represents roughly $10-20 \%$ of the global vegetation carbon with about $73 \%$

85 of the high latitude vegetation carbon located in Eurasia (McGuire et al., 2009, 2010). The size

86 of these carbon pools triggered the interest of researchers studying the global carbon cycle and

87 its response to climate change. The Arctic has experienced a larger increase of mean annual air

88 temperature (MAAT) over the last few decades (IPCC 2007) relative to the global average along

89 with a shift in the total flow and distribution of flow in high latitude rivers (Peterson et al., 2002;

90 Walvoord and Striegl, 2007). Temperature and moisture are key parameters governing the fate of

91 organic matter by influencing vegetation, permafrost stability, peat formation and

92 decomposition, and the frequency of forest fires. The transfer of carbon from high latitude

93 watersheds to the Arctic Ocean and the atmosphere will be partitioned between gaseous forms

$94\left(\mathrm{CO}_{2}\right.$ and $\left.\mathrm{CH}_{4}\right)$ and dissolved and particulate carbon in the rivers. Recent estimates for these 
95 fluxes indicate that the large Arctic watersheds are currently net sinks for $\mathrm{CO}_{2}\left(200-400 \mathrm{Tgyr}^{-1}\right.$;

96 McGuire et al., 2009), net sources for $\mathrm{CH}_{4}\left(33-46 \mathrm{TgCyr}^{-1}\right.$; McGuire et al., 2009), and deliver

97 between 25 and $36 \mathrm{TgCyr}^{-1}$ in the form of dissolved organic carbon (DOC) to the Arctic Ocean

98 (Raymond et al., 2007, Holmes et al., 2011). How these large high latitude watersheds, with their

99 immense carbon pools, will respond to climate change is still highly uncertain.

100 The large Arctic rivers have been the focus of numerous studies over the last few years

101 establishing these rivers as important conduits of DOC and dissolved inorganic carbon (DIC)

102 from the watersheds to the Arctic Ocean (Holmes et al., 2011, Prokushkin et al., 2011). The

103 rivers are characterized by strong seasonal fluctuations in hydrology and high concentrations of

104 DOC of predominantly modern age (Amon and Meon, 2004, Benner at al., 2005, Neff et al.,

105 2006, Raymond et al., 2007). However, we still have a very limited understanding of what

106 sources of organic matter predominate during the different stages of the hydrograph in each of

107 the major Arctic rivers. Knowing the sources (vegetation, soil, peat etc.) of organic matter is

108 crucial if we want to predict the effect that changing climate conditions will have on the transfer

109 of carbon from land to sea. In this study we focus on the lignin phenol composition of river

110 dissolved organic matter (DOM) from the six largest Arctic rivers in order to identify sources

111 and seasonal differences of DOC inputs to these rivers with the purpose to relate the chemical

112 composition of DOC to respective contributions of vegetation, bogs, and soils, and how this

113 affects terrestrial DOC input to the Arctic Ocean.

114

115 2. METHODS:

$116 \quad$ 2.1. Study area 
117 The distribution and size of the six largest Arctic watersheds are shown in Fig. 1, with the 118 dots indicating the approximate sampling location. Of the six rivers, four are located in Siberia

119 (Ob, Yenisei, Lena and Kolyma), and two in North America (Mackenzie, and Yukon).

120 Generally, snow and river ice begin to thaw in May with freshet occurring in late May, early

121 June. Approximately $31-45 \%$ of the annual discharge occurs during the freshet period. The

122 northernmost part of the watersheds is characterized by continuous permafrost, and shifts to

123 discontinuous and then sporadic permafrost towards the south, with the exception of the Kolyma

124 watershed, which is underlain by continuous permafrost throughout.

125 The Mackenzie River is the fourth largest river in terms of discharge $\left(298 \mathrm{~km}^{3} \mathrm{yr}^{-1}\right)$

126 (Holmes et al., 2011) draining into the Arctic Ocean. The watershed is $1.78 \times 10^{6} \mathrm{~km}^{2}$ and

127 stretches from the Great Slave Lake in the Northwest Territories of Canada to the Beaufort Sea.

128 The Mackenzie supplies the Beaufort Sea with approximately $1.4 \mathrm{Tg}$ of DOC per year (Raymond

129 et al., 2007; Holmes et al., 2011). Sedimentary bedrock underlying the catchment consists of

130 carbonates, shales, siltstones, mudstones and till is the dominant parent material. Dominant soil

131 types include Orthic, Regosolic, and Gleysolic Turbic Cryosols (Timoney et al., 1993).

132 Vegetation in the north consists of treeless tussock tundra with the dominant groups being

133 legumes, carices and mosses (Arctostaphylos rubra, Dryas integrifolia, Hedysarum alpinum,

134 Lupinus arcticus, Ditrichum flexicaule; Timoney et al., 1993). Boreal coniferous forest

135 dominates the southern parts of the watershed with mainly white spruce (Picea glauca) in the

136 north and black spruce (Picea mariana) in the south (Goni et al., 2000). The Mackenzie

137 watershed is characterized by large lakes (covering $10 \%$ of the drainage basin area), $35 \%$ forest, $138 \quad 30 \%$ grassland, and 10\% shrubland (Table 1). 
The Yukon River in Alaska is the fourth largest river in North America. Its discharge 140 averages $208 \mathrm{~km}^{3}$ annually and the drainage basin covers $0.830 \times 10^{6} \mathrm{~km}^{2}$ (Table 1 , Holmes et

141 al., 2011). Of the 6 rivers studied in this project the Yukon is the only one that does not directly

142 drain into the Arctic Ocean, but into the Bering Sea. DOC discharge of the Yukon is roughly 1.5

143 TgC per year (Raymond et al., 2007; Holmes et al., 2011). The watershed is situated between the

144 Central and Eastern Brooks Range in the north and the Alaska Range and Wrangell-St. Elias

145 Mountains to the south. The mountainous terrain creates a steeper mean slope $\left(2.93 \mathrm{~m} \mathrm{~km}^{-1}\right)$,

146 higher mean elevation $(690 \mathrm{~m})$ and higher maximum elevation $(6100 \mathrm{~m})$ than the other rivers

147 studied here. Geology for the Yukon is complex reflecting the tectonic activity of the region

148 (Brabets et al., 2000). Generally, the age of rocks range from Precambrian to Holocene and are

149 composed of unconsolidated deposits and consolidated rocks (Brabets et al., 2000). Sedimentary

150 rocks are primarily composed of sandstone, siltstone, shale and limestone but certain locations

151 can contain smaller amounts of coal, mudstone, conglomerate, dolomite and chert (Brabets et al.,

152 2000). Volcanic rocks have a variable composition ranging from rhyolite, andesite, basalt,

153 sandstone, and chert (Brabets et al., 2000). Paleozoic metamorphic rocks are present over much

154 of the Yukon-Tanana upland and are composed of gneiss, schist, phyllite, and quartzite (Brabets

155 et al., 2000). The most abundant soil types within the Yukon watershed are Cryosols and

156 Cambisols with minor amounts of Regosols, and Mollisols (Brabets et al., 2000). Approximately

$15720 \%$ of the catchment is covered by spruce forest, white (Picea glauca) in well drained sites and

158 black (Picea mariana) in lowland sites (Brabets et al., 2000), about 40\% by grassland, $20 \%$ by

159 shrubland, and $8 \%$ by open water and wetlands (Table 1) associated with the low land areas.

160 Note that other studies give higher estimates for the contribution of low-lying wetlands in the

161 Yukon Basin (30\%; O’Donnell et al., 2010). 
The $\mathrm{Ob}$ River is the westernmost of the Siberian rivers studied in this project. Its

163 discharge averages $427 \mathrm{~km}^{3} \mathrm{yr}^{-1}$ or $15 \%$ of total freshwater flow into Arctic Ocean and the

164 drainage basin is approximately $2.99 \times 10^{6} \mathrm{~km}^{2}$ (Table 1 ; Holmes et al., 2011). DOC discharge

165 totals 3.05-4.2 $\mathrm{Tg} \mathrm{yr}^{-1}$ (Raymond et al., 2007; Holmes et al., 2011). Of the Siberian rivers

166 studied herein the $\mathrm{Ob}$ experiences the mildest climate and therefore has the least amount of

167 permafrost (4-10\%) within its catchment (Zhang et al., 1999). The source of this river is in the

168 Altai Mountains and extends to the Kara Sea with a total length of $3977 \mathrm{~km}$. Most of the lower

169 reaches of the catchment are relatively flat with altitudes of 50-150 m (Astakhov, 1991) and

170 slopes between 0-2\% (Stolbovoi et al., 1997), which creates enormous flood plains. The

171 mountainous region of the upper river has elevations of $\sim 4000 \mathrm{~m}$ and a steeper slope (30-60\%;

172 Stolbovoi et al., 1997) creating an average slope of $1.28 \mathrm{~m} \mathrm{~km}^{-1}$ (Table 1). The Ob River

173 watershed is more populated relative to the Yenisei and Lena catchment, and is more influenced

174 by industrial activities and agricultural development (Yang et al., 2004). The bedrocks include

175 granites, clayey sandstone and limestone (Gordeev et al., 2004). Soils are mainly Gleysols,

176 Podsols and Histosols with minor portions of Chernozems and Podzoluvisols (Stolbovoi et al.,

177 1997). The $\mathrm{Ob}$ is unique among the other rivers because it contains within its watershed the

178 largest peat bog system on the planet. The western Siberian lowlands extend over $900,000 \mathrm{~km}^{2}$

179 (Kremenetski et al., 2003) and are a recognized source of methane (Smith et al., 2004).

180 Vegetation is more variable in this watershed compared with the others because of its milder

181 climate, but forests include pine and birch species with reed and sphagnum mosses being

182 dominant in the peat bog system (Wagner, 1997; Zhulidov et al., 1997; Gordeev et al., 2004).

183 Forests cover $39 \%$, croplands $23 \%$, grasslands $16 \%$, and wetlands about $9 \%$ of the drainage 
184 basin (based on satellite derived vegetation maps, Table 1). However, based on the estimate of 185 Kremenetski et al. (2003) the peat bog system would make up about $30 \%$ of the drainage basin. 186 The Yenisei is the longest river $(4803 \mathrm{~km})$, has the greatest discharge (averaging 636 $\left.187 \mathrm{~km}^{3} \mathrm{yr}^{-1}\right)$ and largest watershed $\left(2.54 \times 10^{6} \mathrm{~km}^{2}\right)$ among all Arctic rivers (Table 1, Holmes et al., 188 2011). DOC discharge from the Yenisei is $4.69 \mathrm{Tg} \mathrm{yr}^{-1}$ (Raymond et al., 2007, Holmes et al., 189 2011). The Yenisei originates in the Sayan Mountains and drains Lake Baikal through the 190 Angara tributary. Along with the Ob the Yenisei flows north into the Kara Sea on the western 191 edge of the Central Siberian Uplands. The mean elevation is $670 \mathrm{~m}$ and average slope is $1.94 \mathrm{~m}$ $192 \mathrm{~km}^{-1}$ (Table 1). Both elevation and slope classes are variable throughout the watershed but 193 abruptly increase nearing the headwaters. Soils are dominated by Podzoluvisols, Cambisols, 194 Podsols in the southern and central parts and have a larger contribution of Cryosols and Gleysols 195 in the northern part (Stolbovoi et al., 1997). The climate is colder than in the Ob watershed, 196 therefore $36-55 \%$ of its watershed is underlain with permafrost (Zhang et al., 1999). Vegetation 197 varies from tundra, mixed taiga and pine forest from north to south. The tundra is dominated by 198 dwarf birch (Betula nana), sedges (Carex canescens, Eriophorum vaginatum) and mosses 199 (Hylocomium proliferum, Polytrichum commune and Sphagnum spp.; Zhulidov et al., 1997, 200 Šantrůčková et al., 2003). The boreal zone or taiga includes extensive areas with larches (Larix 201 sibiricaa, L. gmelinii), spruce (Picea obovata), birch (Betula sp.) and pine (Pinus sibirica, $P$. 202 sylvestris) as the dominant species and any number of subdominant plants including Vaccinium 203 spp., Ledum spp., horsetails (Equisetum pratense and E. sylvaticum), berries (Rubus arcticus and 204 R. chamaemorus), mosses (Hylocomium proliferum, Pleurozium schreberi, Cladonia spp., and 205 Sphagnum spp) and lichens (Cetraria spp., Cladonia spp. Etc; Zhulidov et al., 1997; Breckle, 206 2002; Šantrůčková et al., 2003). Towards the south there is a transition into Scots pine forests 
207 (Pinus sylvestris; Šantrůčková et al., 2003) and dark conifer taiga near the headstream (Sayan

208 Mountains). The extensive larch forests are unique to central and east Siberia, but are absent

209 from the watersheds of North American rivers (Strassburger, 1983; Breckle, 2002). In general,

210 vegetation in the Yenisei watershed is dominated by forests ( $68 \%$ of watershed area) with much

211 smaller contributions of shrubland (9\%), grassland (7\%), and cropland (6\%; Table 1).

212 The Lena is the second largest Arctic river in terms of discharge (averaging $581 \mathrm{~km}^{3} \mathrm{yr}^{-1}$;

213 Table 1) and provides the Laptev Sea with 5.6 - 5.8 Tg of DOC per year (Raymond et al., 2007;

214 Holmes et al., 2011). The river is bound by the mountains of the Baikal region in the south, the

215 Verkhoyansk Ridge to the east, the Central Siberian Uplands in the west and flows into the

216 Laptev Sea through a complex braided network of channels (Zhulidov et al., 1997). The total

217 length of the river is $4387 \mathrm{~km}$ and its watershed covers $2.46 \times 10^{6} \mathrm{~km}^{2}$ (Table 1 ). The

218 catchment's average slope is $1.83 \mathrm{~m} \mathrm{~km}^{-1}$, and the mean and maximum elevations are 560 and

$2192830 \mathrm{~m}$, respectively. Permafrost underlies 78-93\% of the watershed (Zhang et al., 1999) with

220 continuous permafrost extending down to $50^{\circ} \mathrm{N}$ in this region. The parent material of the

221 northern to middle watershed is mostly Cambrian and Precambrian limestones, with Jurassic to

222 Cretaceous aged terrigenous sediments and Quaternary alluvial deposits (Rachold, 1999). The

223 southern parts of the watershed are composed of Proterozoic gneiss, shists, quartzites, and

224 marbleized limestones (Rachold, 1999). Soils are mainly Cryosols, Cambisols, and Podsols with

225 minor amounts of Fluvisols and Podzoluvisols (Stolbovoi et al., 1997). Severe climate limits the

226 growth of most species in this region except for larch forests (L. cajanderi), which occupy much

227 of the watershed (Wagner, 1997; Breckle, 2002). To the south where conditions are less severe,

228 pine and birch forests become more abundant (Wagner, 1997; Zhulidov et al., 1997). The Lena 
229 watershed has the most extensive forest area ( $72 \%$ of the watershed) and about $12 \%$ of shrubland 230 (Table 1).

231 The Kolyma is the smallest of the rivers studied in this project. Its discharge averages 111

$232 \mathrm{~km}^{3}$ annually and drains $0.65 \times 10^{6} \mathrm{~km}^{2}$ (Table 1, Holmes et al., 2011). The Kolyma River has

233 the lowest DOC discharge of the rivers studied here with estimates ranging from $0.46-0.82 \mathrm{TgC}$

234 per year (Rachold et al., 2004; Holmes et al., 2011). It is the easternmost Siberian river and is

235 bounded by the Kolyma Mountains to the southeast and the Chersky Ridge to the southwest.

236 The average slope is $2.16 \mathrm{~m} \mathrm{~km}^{-1}$, and mean and maximum elevations are 490 and $2560 \mathrm{~m}$,

237 respectively. Soils are dominated by Cryosols and also include Gleysols, Cambisols, Podsols,

238 and Histosols (Stolbovoi et al., 1997). Tree vegetation is limited to larch forests (L. cajanderi)

239 which dominate most of the watershed (Wagner, 1997). Forest cover in the Kolyma watershed is

$24049 \%$, however, lower estimates $(10 \%)$ have also been reported depending on the satellite data

241 source (see Table 1). Shrublands make up another important section of the watershed with about

$24235 \%$ (Table 1).

$244 \quad$ 2.2. Sampling

245 The PARTNERS Project was coordinated by a core group at the Marine Biological

246 Laboratory (MBL) in Woods Hole, USA. Sampling times and frequencies were planned by this

247 group and executed by local collaborators following on-site training by core group members

248 (McClelland et al., 2008; Holmes et al., 2011). Samples were filtered and preserved in the field

249 before shipment to MBL. At the end of each season frozen samples were shipped to involved

250 principal investigators. 
Samples used in this study were collected during the years 2003-2007. Discharge data has

252 been recorded from gauging stations since 1936 for the Ob, Yenisei, and Lena Rivers. Similar

253 gauging stations were established on the Kolyma, Mackenzie and Yukon between 1968 and 1978

254 and each continues to generate data. PARTNERS samples were collected near these gauging

255 stations at the following locations (Fig. 1); Tsiigehtchic for the Mackenzie River (about $300 \mathrm{~km}$

256 upstream from the Arctic Ocean), Pilot Station for the Yukon (about $200 \mathrm{~km}$ upstream from the

257 Arctic Ocean), Salekhard for the Ob (about $1000 \mathrm{~km}$ upstream from the Arctic Ocean), Dudinka

258 for the Yenisei (600 km upstream from the Arctic Ocean), Zhigansk for the Lena (850 km

259 upstream from the Arctic Ocean) and Cherskiy for the Kolyma (about $100 \mathrm{~km}$ upstream the

260 Arctic Ocean). Sampling was conducted at various times of the year to obtain a representative

261 data set reflecting the changing seasonal hydrograph, including sampling under ice cover during

262 winter. The collection device was a torpedo shaped, Teflon coated, $60 \mathrm{~kg}$, depth integrated

263 sampler (US D-96). The rivers were sampled at five different locations along a cross-channel

264 transect and combined into one homogeneous sample using a Teflon churn. With the exception

265 of winter samples, which were collected by drilling a hole in the ice, each water sample is

266 representative not only of surface to bottom, but cross-channel chemistry. Water from the Teflon

267 churn was then filtered ( $0.45 \mu \mathrm{m}$ Pall Aquaprep 600 capsule filters) into acid washed 1 liter

268 polycarbonate bottles and frozen. All samples remained frozen and in the dark during shipment

269 to MBL and final distribution to project participants. DOC and lignin phenol concentrations

270 presented in this study were determined in these I liter samples.

\section{$271 \quad$ 2.3. Dissolved Organic Carbon}

272 DOC concentrations were measured on a MQ-1001 TOC analyser (MQ-Scientific)

273 according to the protocol of Qian and Mopper (1996) and Peterson et al. (2003). Potassium 
274 hydrogen phthalate was used for standards and a daily calibration curve was measured ranging

275 from 200 to $2000 \mu \mathrm{M}$ C. Deep sea reference (DSR) material supplied by D. Hansell (University

276 of Miami) was run daily to assure proper instrument performance. The residual standard

277 deviation on this instrument averaged $2.5 \%$ for the river samples, and milliQ water blanks

278 averaged $0.12 \mathrm{mg} \mathrm{Cl}^{-1}$. The DSR values varied between 40 and $55 \mu \mathrm{mol}^{-1} \mathrm{C}_{\text {based }}$ on the "wide

279 range" calibration curves.

280

281 2.4. Lignin Phenols

282 About $1 \mathrm{~L}$ of river water was filtered through a $0.2 \mu \mathrm{m}$ pore size polycarbonate filter 283 cartridge and acidified to $\mathrm{pH} 2.5$ using concentrated $\mathrm{HCl}$ (reagent grade). Lignin phenols were 284 extracted by solid phase extraction (SPE) using $60 \mathrm{CC} / 10$ gram $\mathrm{C} 18$ bonded phase columns 285 (Varian) that were pre-cleaned with $50 \mathrm{ml} \mathrm{HPLC}$ grade methanol followed by $100 \mathrm{ml}$ acidified 286 (pH 2.5) MQ water just before sample extraction, and then eluted with $35 \mathrm{ml}$ HPLC grade 287 methanol into a $250 \mathrm{ml}$ precombusted flask (Louchouarn et al., 2000). The samples in the flasks 288 were dried in a Savant SpeedVac (SC210A) for 12-24 hours and dissolved in 3ml 2N NaOH for 289 CuO oxidation.

290 Alkaline $\mathrm{CuO}$ oxidation of DOM and quantification of lignin oxidation products (LOP) 291 was performed according to the methods described in detail in Louchouarn et al. $(2000,2010)$ 292 and Kuo et al. (2008). Briefly, each SPE eluent was sonicated twice with $1.5 \mathrm{~mL}$ of $8 \% \mathrm{NaOH}$ 293 (pre-sparged with Ar) to remove the isolated DOM and residues adhered to the Savant flasks. 294 The two $1.5 \mathrm{ml}$ aliquots of $\mathrm{NaOH}$ with $\mathrm{DOM}$ were then transferred to a reaction mini-vessels 295 pre-loaded with $\mathrm{CuO}(\sim 300 \mathrm{mg})$ and $\mathrm{Fe}\left(\mathrm{NH}_{4}\right)_{2}\left(\mathrm{SO}_{4}\right)_{2} \cdot 6 \mathrm{H}_{2} \mathrm{O}(\sim 50 \mathrm{mg})$ and then heated $\left(155^{\circ} \mathrm{C}\right.$ for $2963 \mathrm{~h}$ ) in a customized Hewlett-Packard 5890 gas chromatograph. Trans-cinnamic acid (CiAD: 3- 
297 phenyl-2-propenoic acid) and ethyl vanillin (EVAL: 3-ethoxy-4-hydroxybenzaldehyde) were 298 used as surrogate standards and were directly added ( $\sim 3-12 \mu \mathrm{g})$ to each mini-vessel after cooling.

299 The $\mathrm{CuO}$ reaction products were re-dissolved in a small volume of pyridine $(200-500 \mu \mathrm{L})$, and

300 derivatized $\left(75^{\circ} \mathrm{C}, 1 \mathrm{~h}\right)$ with $N, O$-bis(trimethylsilyl) trifluoroacetamide (BSTFA) containing $1 \%$ 301 trimethylchlorosilane (TMCS).

302 Separation and quantification of trimethylsilyl derivatives of $\mathrm{CuO}$ oxidation by-products 303 were performed using gas chromatography-mass spectrometry (GC/MS) with a Varian Ion Trap $3043800 / 4000$ system fitted with a fused silica column (VF 5MS, $30 \mathrm{~m}$ x $0.25 \mathrm{~mm}$ i.d. or $60 \mathrm{~m} \mathrm{x}$ $3050.25 \mathrm{~mm}$ i.d.; Varian Inc.). Each sample was injected, under split less mode, into a deactivated 306 glass liner inserted into the GC injection port; He was the carrier gas $\left(\sim 1.0 \mathrm{~mL} \mathrm{~min}^{-1}\right)$. The GC 307 oven was programmed from $65^{\circ} \mathrm{C}$ (with a $2 \mathrm{~min}$ initial delay) to $300^{\circ} \mathrm{C}$ (held $10 \mathrm{~min}$ ) using a $3084^{\circ} \mathrm{C} / \mathrm{min}$ temperature ramp. The $\mathrm{GC}$ injector and $\mathrm{GC} / \mathrm{MS}$ interface were both maintained at $309280^{\circ} \mathrm{C}$ and $270^{\circ} \mathrm{C}$, respectively. The mass spectrometer was operated in the electron ionization 310 mode (EI, $70 \mathrm{eV})$ using full scan (FS) in the 50-500 mass range. Compound identification was

311 performed using GC retention times and by comparing full mass spectra with those of

312 commercially available standards. Trimethylsilyl derivatives were detected using 3-5 ions for 313 identification of each $\mathrm{CuO}$ oxidation product, but one for quantification. Cinnamic Acid (CiAD)

314 was used for calculation of response factors and LOP concentrations. However, we monitored

315 the ratio of EVAL/CiAD as a quality control parameter due to the sensitivity of aldehydes to 316 degradation or vaporization compared to acids.

317 The analytical precision of the major $\mathrm{CuO}$-oxidation products and related parameters was 318 derived from replicate analyses of standard materials including estuarine sediments (NIST SRM 3191944 and SRM 1941b) and dried fulvic acid (IHSS 1S101F). The average variability for all 
320 parameters was better than 10\% (Louchouarn et al., 2010). Reagent blanks and SRMs were

321 processed daily as additional quality control measures. Analysis of SPE blanks found only trace

322 contamination of the acidic groups (vanillic acid, syringic acid, $p$-hydroxybenzoic acid, 3,5

323 dihydroxybenzoic acid). With this approach we were confident to quantify the following $\mathrm{CuO}$

324 oxidation products: vanillin, vanillic acid, acetovanillone, syringealdehyde, syringic acid,

325 acetosyringone, p-coumaric acid, ferulic acid, p-hydroxybenzaldehyde, p-hydroxyacetophenone,

326 p-hydroxybenzoic acid, and 3,5 dihydroxybenzoic acid.

\subsection{Calculations}

Discharge-weighted-average concentrations presented in Table 2 were calculated as

330 follows. The relationship between the available daily discharge and the different DOM

331 parameters (17 observations per river) was used to derive the function with the best statistical fit.

332 The equations were then used to derive values for each month of the year. The value for each

333 month was then multiplied by the respective monthly discharge and then divided by the total

334 annual discharge to derive a discharge-weighted mean.

335 The relative contributions of potential DOM sources (gymnosperm, angiosperm plants,

336 mosses, soils, and peat) were estimated based on the following 4 equations.

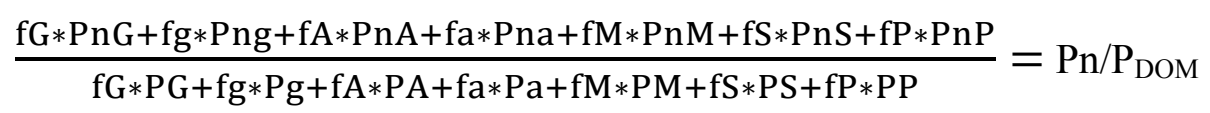


341 The fractions (f) in the equations were adjusted until all 4 equations returned similar percentages

342 for the different sources. This was done by trial and error. We used 4 lignin oxidation derived

343 parameters, the ratio of syringyl to vanillyl phenols (S/V), the ratio of cynamyl to vanillyl (C/V)

344 phenols, the ratio of $\mathrm{p}$-hydroxybenzenes to vanillyl phenols $(\mathrm{P} / \mathrm{V})$, and the ratio of $\mathrm{p}$ -

345 hydroxyacetophenone to $\mathrm{p}$-hydroxybenzenes $(\mathrm{Pn} / \mathrm{P})$, and 7 potential sources including

346 gymnosperm wood (G), gymnosperm needles (g), angiosperm wood (A), angiosperm leaves (a),

347 moss (M), soil (S), and peat (P). The endmember values for these sources are given in Table 4

348 and a detailed description of the parameters is given in the discussion.

\section{3. RESULTS}

351 DOC concentrations increased with discharge with elevated levels during the spring freshet and

352 lowest concentrations during winter base flow conditions. In short, average DOC concentrations

353 were highest in the Lena $\left(11.4-11.9 \mathrm{mg}^{-1}\right)$ and lowest in the Mackenzie $\left(4.2-4.4 \mathrm{mg}^{-1}\right.$;

354 Table 2). The annual DOC load from these rivers varied considerably (Table 3) ranging from

$3556.47 \mathrm{Tg}$ DOC $\mathrm{yr}^{-1}$ (36\% of the total) in the Lena River to $0.71{\mathrm{Tg} \mathrm{DOC} \mathrm{yr}^{-1}}^{-1}(3.9 \%$ of total) in the

356 Kolyma. Together, the Eurasian rivers contribute about $84 \%$ of the annual DOC discharge to the

357 Arctic Ocean.

358 Lignin phenol concentrations based on the sum of vanillyl, syringyl, and cinnamyl

359 phenols $\left(\Sigma_{8}\right)$ are, like DOC, strongly correlated with discharge, but not to the same extent in the 360 different rivers. Similar to DOC, most lignin is discharged during the 2 months of spring freshet

361 (49-78\%; Table 3). While lignin increased by more than an order of magnitude during the freshet

362 (from $<3$ ug $1^{-1}$ to $>100$ ug $1^{-1}$ ) in most rivers, the lignin levels in the Mackenzie only increased

363 by a factor of 4 (from $\sim 5$ to $\sim 25 \mathrm{ug}^{-1}$ ). The relationship between lignin concentrations and 
364 discharge was different for the 6 rivers (Fig. 2) with some rivers (Yenisei and Mackenzie)

365 displaying a strong linear relationship while other rivers (Ob, Lena, Yukon) suggested that DOM

366 saturation or dilution effects occur towards the end of the peak flow period. Highest lignin

367 concentrations were found in the Lena with freshet values exceeding $400 \mu \mathrm{g}$ lignin phenols $1^{-1}$

$368\left(\Sigma_{8}\right)$, a mean value of $135 \mu \mathrm{g} 1^{-1}$ and a discharge weighted mean of $102 \mu \mathrm{g} 1^{-1}$ (Table 2). These

369 freshet values are among the highest lignin concentrations reported in natural waters. The lowest

370 lignin concentrations were detected in the Mackenzie with respective mean and discharge

371 weighted mean values of 12.6 and $12.7 \mu \mathrm{g} \mathrm{l}^{-1}$. Second largest lignin concentrations were found in

372 the Yenisei with 109 and $86 \mu \mathrm{g}^{-1}$ for the mean and discharge weighted mean, followed by the

373 Ob with a mean concentration of 66 and a discharge weighted mean of $61 \mu \mathrm{g} 1^{-1}$ which was very

374 similar to concentrations in the Yukon and Kolyma (Table 2). The Lena is the single most

375 important source of lignin to the Arctic Ocean with 91.6 Gg lignin per year (47.7\%), followed by

376 the Yenisei with $54.3 \mathrm{Gg}$ lignin per year (28.3\%). The Mackenzie on the other hand only

377 contributes $3.6 \mathrm{Gg}$ lignin per year (1.9\%). Taken together the 3 largest Eurasian rivers, Lena,

378 Yenisei and $\mathrm{Ob}$ contribute more than $87 \%$ of the lignin phenols to the Arctic Ocean and release

$37967 \%$ of the total annual pan-Arctic lignin discharge during the 2 month of spring freshet (Table

380 3). Lignin yield $\left(\Lambda_{8}\right)$, a measure of the relative contribution of lignin to total DOC, is also

381 strongly related to discharge (data not shown) with elevated values during freshet. The

382 differences in the lignin yield between peak, intermediate, and low discharge periods, was least

383 pronounced in the Mackenzie (Fig. 3B). Values ranged from $<0.2$ to $>2.5 \mathrm{mg}$ lignin $100 \mathrm{mg}^{-1}$

384 DOC and the discharge weighted means were $0.20,0.53,0.55,0.77,0.77$, and $2.14 \mathrm{mg}$ lignin

$385100 \mathrm{mg}^{-1}$ DOC for Mackenzie, Ob, Yukon, Kolyma, Yenisei, and Lena, respectively (Table 2). 
Lignin monomer ratios reflect a strong seasonal signal, related to discharge, but also

387 differ among some of the rivers. The ratios of vanillic acid to vanillin $(\mathrm{Ad} / \mathrm{Al})_{\mathrm{v}}$ and syringic acid 388 to syringealdehyde $(\mathrm{Ad} / \mathrm{Al})_{\mathrm{s}}$, often used as a diagenetic indicator, were highest during peak flow 389 and consistently decreased from peak flow conditions to base flow conditions (Table 2, Fig.

$3903 \mathrm{CD})$, contrary to the common diagenetic pattern. Discharge weighted means of $(\mathrm{Ad} / \mathrm{Al})_{\mathrm{v}}$ ratios 391 were slightly lower in Yukon and Mackenzie $(\sim 0.8)$ than in the Eurasian rivers (1.0-1.1). The

392 source indicator ratios S/V (syringyls/vanillyls) and C/V (cynnamyls/vanillyls) also display a

393 seasonal change with lower ratios during the spring freshet except for $\mathrm{S} / \mathrm{V}$ ratios in $\mathrm{Ob}$ and 394 Mackenzie (Table 2, Fig. 3EF). S/V ratios were slightly higher in the Yukon, Ob and Kolyma 395 (0.4-0.6), relative to the Mackenzie, Lena, and Yenisei ( 0.3). The Yukon and the Ob rivers also 396 stand out with respect to $\mathrm{C} / \mathrm{V}$ ratios which are higher $(>0.1)$ in these two rivers relative to the 397 other four $(<0.1)$. Yukon and Ob also had more elevated values for three, less commonly used, 398 lignin indicators, the ratio of p-coumaric acid to ferulic acid ( $\mathrm{Cad} / \mathrm{Fad}), 3,5$-dihydroxybenzoic $399 \mathrm{acid} /$ vanillyls $(3,5 \mathrm{Bd} / \mathrm{V})$, and p-hydroxybenzenes to vanillyls $(\mathrm{P} / \mathrm{V})$. All of these typically 400 increase from freshet to mid and base flow in all rivers, but in the Yukon and Ob this trend was 401 especially pronounced (Table 2, Fig. 3G-I). Seasonal trends and differences among rivers were 402 also found in lignin derived phenol parameters recently used as source indicators including the 403 ratio of p-hydroxyacetophenone to total p-hydroxybenzenes $(\mathrm{Pn} / \mathrm{P})$ and the yield of $\mathrm{Pn}$, both 404 potential indicators for peat and moss contributions, which showed generally lower values during 405 freshet in all rivers (Table 2, Fig. 3J,K). Pn yields were clearly elevated in Ob and Yukon, 406 particularly during the low-flow seasons, but had high variability during that time. The vanillyl 407 yield (Fig. 3L) has recently been used as a measure for vascular plant contribution in the Yukon 
408 River (Spencer et al. 2009) and mirrors the $\Lambda_{8}$ values with much higher values during the spring 409 flood, particularly in the Lena and Yenisei.

410 Lignin phenol concentrations and monomer composition are strongly related to the

411 average ${ }^{14} \mathrm{C}$-age of DOC. All rivers except the Mackenzie show an increase of lignin phenol

412 concentrations and yields with younger average DOC-age (Fig. 4). The relationship between the

413 lignin concentration and ${ }^{14} \mathrm{C}$ age of DOC is significant in all rivers except the Mackenzie (Fig 4).

414 In the Mackenzie there is actually a negative trend, however, the relationship between lignin and

415 DOC-age is not significant (Fig. 4E). Most of the lignin monomer ratios are also related to the

416 average ${ }^{14} \mathrm{C}$-age of DOC (Fig. 5). While $\mathrm{Ad} / \mathrm{Al}$ ratios increased with decreasing average DOC-

417 age (contrary to the common believe; Fig 5A), the $\mathrm{C} / \mathrm{V}, \mathrm{Cad} / \mathrm{Fad}, 3,5 \mathrm{Bd} / \mathrm{V}, \mathrm{P} / \mathrm{V}$, and $\mathrm{Pn} / \mathrm{P}$ ratios

418 all decreased in younger DOC (Fig. 5C-G). S/V ratios changed the least with age, except for the

$419 \mathrm{Ob}$, which has elevated $\mathrm{S} / \mathrm{V}$ ratios at intermediate ${ }^{14} \mathrm{C}$-ages of DOC (Fig 5B). The yield of p-

420 hydroxyacetophenone had a weaker negative relationship with ${ }^{14} \mathrm{C}$-age of DOC and increasing

421 values with older DOC was only obvious in $\mathrm{Ob}$ and Yukon (Fig. 5H), while the yield of vanillyl

422 phenols showed a strong positive exponential relationship with ${ }^{14} \mathrm{C}$-age across all the rivers (Fig. 423 5I).

424

425 4. DISCUSSION

426

427 4.1. Dissolved organic carbon

428 Dissolved organic carbon discharge from the large Arctic rivers sampled during the PARTNERS

429 program has been discussed in several previous studies (Cooper et al., 2005; Raymond et al.,

430 2007; Cooper et al., 2008; Holmes et al., 2011). The DOC data presented here were measured in 
431 the samples collected for lignin analysis and represent a replicate data set to the PARTNERS

432 data. The two data sets return almost identical estimates for the total annual DOC export of

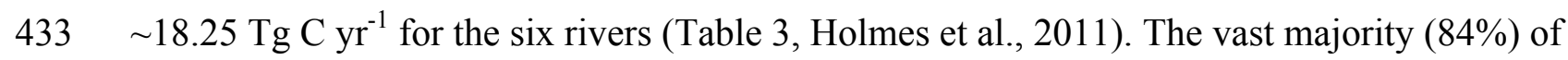

434 river DOC is discharged by the Eurasian rivers with a relatively small (16\%) contribution from

435 the large North American rivers. In addition, a significant portion of the North American river

436 DOM is exported through the Canadian Archipelago (Guay et al., 2009; Macdonald et al., 2002)

437 before entering the Canada Basin. This has important implications for the interpretation of the 438 geographical distribution of terrestrial DOM within the Arctic Ocean.

\section{$440 \quad$ 4.2. Lignin phenols}

441 The seasonal change of DOM composition has been documented for the Yukon (Striegl et al., 442 2005, 2007; Guo and Macdonald, 2006; Spencer et al., 2008, 2009) and Kolyma (Finlay et al., 443 2006; Neff et al., 2006) rivers indicating a general shift from recently produced DOM during 444 freshet to more aged DOM during winter base-flow. While this general trend is also reflected in 445 the other large Arctic rivers (Koehler et al., 2003; Raymond et al., 2007; Stedmon et al., 2011), 446 we still have a very limited understanding of the sources of DOM and how they are affected by 447 the changing hydrograph and the different watershed characteristics. Lignin phenols are 448 produced by vascular plants and their presence in DOM can help to characterize and quantify 449 sources in the overall DOM pool. Differences in lignin concentrations and compositions between 450 rivers are important when estimating their relative contributions to the Arctic Ocean and 451 interpreting the distribution of terrestrial organic matter within the Arctic Ocean.

452 The role of diagenetic and/or sorption processes for the lignin concentration and yield in 453 the rivers is reflected in the relationships between the average ${ }^{14} \mathrm{C}$-age of DOC and lignin 
454 concentrations (Fig. 4). The younger or "fresher" the river DOM is, the higher is the

455 concentrations of lignin. This is the most direct evidence that a large proportion of the DOM

456 exported by large Arctic rivers during the spring freshet comes from recently produced vascular

457 plant material with little exposure to microbial degradation and sub soils. The strong relationship

458 between lignin concentration and ${ }^{14} \mathrm{C}$-age is consistent with previous observations in the Arctic

459 Ocean where the age of DOC decreased with increasing concentrations of lignin (Benner et al.,

460 2004). The Mackenzie was the only river showing a negative, albeit not significant, trend (Fig.

461 4E), which could be related to the rapid removal of fresh vascular plant derived DOM during

462 freshet. $\Delta{ }^{14} \mathrm{C}$-values never exceeded $40 \%$ in the Mackenzie compared to $\Delta^{14} \mathrm{C}$-values $>70 \%$ in

463 all the other rivers during freshet. Reasons for the markedly different lignin concentrations and

464 lignin- $\Delta^{14} \mathrm{C}$ relationship in the Mackenzie River are not clear but could also involve the much

465 higher concentration of suspended matter (SPM) in the Mackenzie, potentially leading to the

466 removal of DOM through sorption onto particles. However, the depleted $\Delta^{14} \mathrm{C}$ values measured

467 in suspended matter (SPM) from the Mackenzie (Goni et al., 2005) would limit the amount of

468 fresh DOM that could be adsorbed onto SPM. The fact that part of the Mackenzie SPM is

469 radiocarbon dead $\left(\Delta^{14} \mathrm{C}\right.$ of $-1000 \%$, Goni et al. 2005$)$ would allow for a maximum of $30 \%$

470 modern carbon contribution to Mackenzie SPM (Goni et al., 2005). The rapid removal of

471 dissolved lignin phenols due to adsorption on fine particles has been suggested in the Amazon

472 River system (Ertel et al., 1986) where blackwater rivers (high in lignin) mix with white water

473 rivers (high in SPM). The same mechanism could be important in the Mackenzie, which has the

474 highest sediment load of all Arctic rivers. Alternatively, the unique abundance of lakes and

475 wetlands in the Mackenzie watershed (the Mackenzie originates in the Great Slave Lake) could

476 alter the proportion of DOM transported down the river. Lakes and wetlands contribute more 
477 than 55\% to the water in the Mackenzie River (Yi et al., 2010). Because open water bodies

478 generally act as a buffer for hydrologic events (Gibson and Prowse, 2002), they can increase the

479 residence time for organic matter in these systems, potentially leading to larger losses of DOM

480 due to degradation or burial before discharge (Cole et al., 2007).

481 The relative composition of lignin phenol monomers has been used as a source as well as

482 a diagenetic indicator of terrestrial organic matter in aquatic and soil systems (Hedges and Mann,

483 1979; Benner et al., 1990; Goni and Hedges, 1992; Opsahl and Benner, 1995; Louchouarn et al.,

484 1999; Opsahl et al., 1999; Hernes and Benner, 2002; Tesi et al., 2007; Houel et al., 2009).

485 Vanillic acid to vanillin or $(\mathrm{Ad} / \mathrm{Al})_{\mathrm{v}}$ and syringic acid to syringealdehyde or $(\mathrm{Ad} / \mathrm{Al})_{\mathrm{s}}$ ratios have

486 been used as diagenetic indicators for soil organic matter as well as particulate and dissolved

487 organic matter in rivers, lakes, and the ocean. Usually, the $\mathrm{Ad} / \mathrm{Al}$ ratios increase with increasing

488 oxidative degradation of organic matter. However, the variation of $\mathrm{Ad} / \mathrm{Al}$ ratios in different

489 lignin sources is large and it has been suggested that leachates from vascular plant litter can also

490 have elevated Ad/Al ratios (Guggenberger and Zech, 1994; Hernes et al., 2007). From our data

491 set it is obvious that $\mathrm{Ad} / \mathrm{Al}$ ratios are consistently affected by the hydrograph (Fig. 3CD) and also

492 show a strong relationship to the radiocarbon age of DOC (Fig 5A). Ad/Al ratios are highest

493 during spring freshet when the average ${ }^{14} \mathrm{C}$ age of DOC is young, indicating that a significant

494 fraction of river DOM comes from recently produced vascular plant and litter leachates during

495 the spring freshet in May and June. Each of the rivers displayed elevated Ad/Al ratios during the

496 spring freshet relative to base flow. Based on discharge weighted mean Ad/Al ratios, the Yukon

497 and the Mackenzie have slightly lower values than the Eurasian rivers, which may be related to

498 the rapid removal of fresh lignin phenols with high Ad/Al ratios or the larger amount of SPM in 
499 the North American rivers. Sorption of DOM to the mineral phase has been connected to

500 changing $\mathrm{Ad} / \mathrm{Al}$ ratios in experimental studies (Hernes et al., 2007).

501 The ratio of syringyl to vanillyl phenols $(\mathrm{S} / \mathrm{V})$ is an indicator for the lignin phenol

502 sources with high ratios indicating angiosperms sources and low $\mathrm{S} / \mathrm{V}$ ratios indicating a

503 gymnosperm source (Hedges and Mann 1979). Most rivers had lower S/V ratios during the

504 spring freshet relative to the base flow values, except for the Ob, which displayed the opposite

505 trend (Fig. 3E). Of all lignin parameters $\mathrm{S} / \mathrm{V}$ ratios were the least affected by the change in DOC

506 age (Fig. 5B), indicating that the shift in $\mathrm{S} / \mathrm{V}$ ratios during the different hydrographic stages

507 reflected a shift in sources as well as diagenetic state. Overall, low S/V ratios indicate

508 gymnosperm vegetation as the most important source of lignin in these rivers, which reflects the

509 dominant form of vegetation in these watersheds. The seasonal variation in $\mathrm{S} / \mathrm{V}$ ratios is almost

510 as big as the differences among rivers, but based on the discharge weighted means the Lena,

511 Yenisei, and Mackenzie have very similar (0.28 -0.31) and relatively low S/V ratios, while the

512 Kolyma, Yukon and $\mathrm{Ob}$ have relatively higher $\mathrm{S} / \mathrm{V}$ ratios $(0.38-0.58$, Fig. 4E). The Ob watershed

513 has the warmest climate of all with a relatively larger contribution from angiosperms as well as

514 an extensive bog system with abundant mosses (Table 1; Breckle, 2002; Strassburger, 1983;

515 Opsahl et al., 1999). Elevated S/V ratios in the Kolyma and Yukon are less obvious, but a study

516 by Lobbes et al. (2002) suggests that rivers that drain mainly higher latitudes and altitudes

517 including the Arctic tundra are characterized by elevated $\mathrm{S} / \mathrm{V}$ ratios. The fact that a large portion

518 of the Yukon and Kolyma watersheds are north of the Arctic Circle with a general shift to

519 flowering tundra plants could explain the elevated S/V ratios. Elevated values of S/V have been

520 reported from high altitude tundra vegetation and soils in northern Alaska (Ugolini et al., 1981). 
521 The watersheds of the Yukon and Kolyma also share extended shrubland areas with 20\% and $52232 \%$, respectively (Table 1$)$.

523 The ratio of cynamyl to vanillyl $(\mathrm{C} / \mathrm{V})$ phenols has been used to distinguish woody lignin

524 from other lignin sources with higher ratios indicating herbaceous plants or sphagnum moss

525 sources. C/V ratios varied less with the hydrograph than the other lignin parameters except in the

526 Yukon and the $\mathrm{Ob}$, which showed increasing $\mathrm{C} / \mathrm{V}$ ratios during mid and low flow conditions

527 (Fig. 3F). Overall, the $\mathrm{C} / \mathrm{V}$ ratios were low $(<0.1)$ for most rivers except for the Yukon and $\mathrm{Ob}$

528 which had $\mathrm{C} / \mathrm{V}$ ratios $>0.1$ throughout the year. This indicates significant input of woody plant

529 material as a source of lignin phenols. It has been indicated that $\mathrm{C} / \mathrm{V}$ ratios decrease with

530 progressive degradation, but in our data set the C/V ratios were actually higher in older DOC

531 (Fig. 5C) potentially reflecting different sources and/or varying sorption behavior of the $\mathrm{V}$ and $\mathrm{C}$

532 phenols. As with $\mathrm{S} / \mathrm{V}$ ratios, elevated $\mathrm{C} / \mathrm{V}$ ratios have been reported for high altitude soils and

533 tundra vegetation (Ugolini et al., 1981) and the Yukon watershed has the highest mean elevation

534 of all the large Arctic rivers. Both, Yukon and Ob watersheds also have a significant contribution

535 of wetland vegetation and grassland (Table 1, O’Donell et al., 2010) likely contributing to

536 slightly elevated $\mathrm{C} / \mathrm{V}$ values. It is noteworthy that $\mathrm{C} / \mathrm{V}$ ratios doubled in the Yukon River during

537 base flow conditions relative to the freshet.

538 Ratios of p-coumaric acid to ferulic acid (CAD/FAD) have also been used as a diagenetic

539 indicator in lake sediments (Houel et al. 2006) due to the preferential degradation of ferulic acid.

540 In addition, p-coumaric acid is believed to be more soluble (Sanger et al., 1997). Both of these

541 processes lead to higher $\mathrm{CAD} / \mathrm{FAD}$ ratios in river DOM. In this data set the $\mathrm{CAD} / \mathrm{FAD}$ ratios

542 stayed fairly constant over the different hydrographic stages except for the Yukon and Ob, which

543 showed increasing ratios during winter base flow conditions (Fig. 3G) and had the highest 
544 average values among all rivers. Most rivers, except the Mackenzie, showed a significant

545 negative correlation between CAD/FAD and $\Delta^{14} \mathrm{C}$-DOC (Fig. 5D) indicating increasing

$546 \mathrm{CAD} / \mathrm{FAD}$ ratios in older DOC. Elevated $\mathrm{CAD} / \mathrm{FAD}$ ratios have also been reported in leaves,

547 needles, wetland vegetation (Table 4), and from tundra soils relative to boreal forest soils

548 (Ugolini et al., 1981). p-coumaric acid is also a significant component in sphagnum moss and

549 wetland soils (Williams et al., 1998) indicating that sources as well as the diagenetic state of

550 organic matter can influence the observed trends in $\mathrm{CAD} / \mathrm{FAD}$ ratios.

551 We also included a number of cupric oxide oxidation products that do not necessarily

552 originate from lignin but have been used along with lignin-derived phenols in soil and aquatic

553 geochemistry. 3,5-dihydroxybenzoic acid (3,5Bd) likely originates from terrestrial sources such

554 as tannins and flavonoids (Goni and Hedges, 1995). Due to the recalcitrant nature of tannins,

$5553,5 \mathrm{Bd} / \mathrm{V}$ ratios have been used as diagenetic indicator for organic matter in soils and sediments

556 (Houel et al., 2006). Alternatively, increasing 3,5Bd/V ratios could indicate more effective

557 sorption of vanillyls relative to $3,5 \mathrm{Bd}$. This is consistent with our data which show a shift in

$5583,5 \mathrm{Bd} / \mathrm{V}$ ratios from low values during freshet to higher values during mid and base flow

559 conditions (Fig. 3H) and a strong relationship to average DOC age (Fig.5E). The 3,5Bd/V ratios

560 (discharge weighted means) were slightly higher in the Yukon, Ob, and Mackenzie than in the

561 Yenisei, Lena, and Kolyma with maximum values above 1.5. Such high values have been

562 reported for mineral soil horizons of boreal forest soils (Houel et al., 2006) as well as from alpine

563 tundra soils in northern Alaska (Ugolini et al., 1981).

564 p-hydroxybenzenes can have several sources, while p-hydroxyacetophenone (Pn) is

565 lignin-derived, p-hydroxybenzaldehyde ( $\mathrm{Pl})$ and p-hydroxybenzoic acid ( $\mathrm{Pd})$ can also be derived

566 from proteins and polysaccharides during cupric oxide oxidation (Goni et al., 2000). High 
567 concentrations of all three p-hydroxybenzenes have been detected in different Sphagnum species 568 as well as in certain peat soils (Williams et al., 1998). Moss and peat are especially enriched in 569 Pn which make up more than $60 \%$ of the sum of all p-hydroxybenzenes in mosses and $30-60 \%$ in 570 peat samples (Williams et al., 1998). In contrast, published $\mathrm{Pn} / \mathrm{P}$ ratios are typically lower for 571 vascular plants (0.18; Hedges et al., 1982), vascular wetland plants (0.22; Williams et al., 1998), 572 boreal lake sediments $(<0.15$; Teisserenc et al., 2010; Houel et al., 2006) and boreal soils (0.14573 0.40; Houel et al. 2006). Published information on p-hydroxybenzenes in DOM is sparse but the 574 few available data also indicate rather low Pn/P ratios for the Amazon River (0.21; Ertel et al., 575 1986), a North American river (0.26; Benner and Kaiser, 2010), and in boreal forest lake DOM 576 ( 0.18, Ouellet et al., 2009). In contrast to the available literature data, we measured elevated 577 concentrations of p-hydroxybenzenes and specifically $\mathrm{Pn} / \mathrm{P}$ ratios in Arctic river DOM (Table 2, 578 Fig. 3J). The fact that $\mathrm{Pn} / \mathrm{P}$ ratios never dropped below about 0.22 , suggests $\mathrm{p}$-hydroxybenzenes 579 are largely lignin-derived in these rivers. $\mathrm{Pn} / \mathrm{P}$ ratios in Arctic rivers range from 0.24 to 0.47 with 580 increasing ratios during base flow conditions and highest values in Yukon and $\mathrm{Ob}$ (Fig. 3J).

581 Relative to the few published $\mathrm{Pn} / \mathrm{P}$ values in freshwater DOM, it seems that large Arctic rivers 582 are characterized by elevated values of p-hydroxyacetophenone. $\mathrm{P} / \mathrm{V}$ ratios in the 6 rivers ranged 583 from 0.26 to 5.0 with a pronounced decrease during the spring freshet (Fig. 3I). P/V ratios in the 584 Amazon (0.68; Ertel et al., 1986), a north American river (0.44; Benner and Kaiser, 2010), and 585 boreal forest lakes (0.68; Ouellet et al., 2009) are similar to average values in the 6 largest Arctic 586 rivers during freshet (Table 2) but lower than $\mathrm{P} / \mathrm{V}$ ratios measured during mid and base flow 587 conditions. $\mathrm{P} / \mathrm{V}$ ratios were highest (>2.0) during base flow in the Yukon and $\mathrm{Ob}$ (Fig. 4I), 588 representing another similarity between these two rivers. $\mathrm{P} / \mathrm{V}$ and $\mathrm{Pn} / \mathrm{P}$ values indicate a 
589 considerable contribution of mosses or peat to the riverine DOM pool, particularly during mid 590 and low flow conditions.

\subsection{Sources of Arctic river DOM}

593 Discharge of DOC and lignin to the Arctic Ocean changes dramatically during the seasons with

594 more than $2 / 3^{\text {rd }}$ of the annual discharge occurring during the two months of spring freshet.

595 Hence, understanding the sources for this quantitatively dominant DOM pool is most important.

596 Potential sources of DOM in rivers include vascular plants and algae. The vascular plant source

597 can enter the river as part of the surface run-off after snowmelt or as part of the subsurface run-

598 off (groundwater) after percolating the upper soil horizons. The highly elevated concentrations of

599 lignin phenols during the spring freshet suggest vascular plants and fresh litter as a dominant

600 source, which agrees with the modern ${ }^{14} \mathrm{C}$-age (Raymond et al., 2007) and the relatively high

$601 \mathrm{C} / \mathrm{N}$ ratios of peak flow DOM (44; Holmes et al., 2011). C/N ratios also allow to roughly

602 distinguish algae-derived DOM (C/N=14; Amon and Meon 2004) and soil-derived DOM

603 (C/N=14-25; Kaiser et al., 2004; Kawahigashi et al., 2006) from vascular plant sources

604 (C/N 54; Amon and Meon, 2004). Based on the reported $\mathrm{C} / \mathrm{N}$ ratios during peak flow in these

605 rivers (Holmes et al., 2011), vascular plants and litter (surface run-off) contribute about 70\% of

606 the DOM and a combination of algae and soil derived DOM contributes the other $30 \%$ of the

607 DOM (soil and algae DOM cannot be distinguished based on $\mathrm{C} / \mathrm{N}$ ratios). An alternative

608 approach to estimate the vascular plant contribution to river DOM was introduced by Hernes et

609 al. (2007) and Spencer et al. (2009) based on the yield of vanillyl phenols. Spencer et al (2009)

610 estimated that 5-55\% of DOM in the Yukon is vascular plant derived depending on the season,

611 with higher percentages during the freshet. If we assume a source endmember of $1.6 \mathrm{mg} / 100 \mathrm{mg}$ 
612 DOC, as given in Hernes et al. (2007), the vascular plant contribution to peak-flow DOM in our 613 study varies between 16\% (Mackenzie) and 87\% (Lena). Based on our V-yield data during peak

614 flow conditions, vascular plants make up most of the riverine DOM. Lowest yields were found in

615 the Mackenzie River and during the late winter base flow, potentially because of selective

616 sorption of LOPs to the mineral phase in soils and rivers (Guggenberger and Zech, 1994; Kaiser

617 et al., 2004). Algae probably contribute little to river DOM during the cold and dark period of the

618 year when the V-yield is the lowest, but mosses, peat, and soil DOM also have low V-yields and

619 are likely important DOM sources during that time. Clearly, the vanillin yield is affected by

620 degradation (Fig. 5I) and sorption processes. Its use as a source indicator is therefore hampered

621 by multiple challenges including endmember characterization and potential changes in yield

622 during degradation/sorption processes.

623 The classical property-property plot of $\mathrm{C} / \mathrm{V}$ and S/V (Fig. 6A) underlines the dominance

624 of gymnosperms as a source of Arctic river DOM. Especially, the Lena and Yenisei peak flow

625 values plot very close to the gymnosperm wood endmember (Fig. 6A). Peak flow values are very

626 low but still show slightly elevated $\mathrm{S} / \mathrm{V}$ and $\mathrm{C} / \mathrm{V}$ values relative to a pure gymnosperm wood

627 source. Because gymnosperm wood and needles are devoid of syringyl phenols, the slightly

628 elevated S/V values point to additional plant sources. Field observations indicate that moss

629 biomass exceeds shrub biomass by a factor of 10 (Prokushkin et al., 2006) suggesting the most

630 likely source with elevated $\mathrm{S} / \mathrm{V}$ values in northern taiga and larch woodlands of Siberia are

631 mosses rather than angiosperms (Prokushkin et al., 2006). However, angiosperms become

632 abundant in the tundra regions of the watersheds as well as in the alpine regions and likely

633 contribute to some degree to the DOM found in the rivers. A prominent moss contribution is

634 consistent with the observed values for Pn-yields (Fig. 5H), P/V and Pn/P (Fig. 6B). A mixture 
635 of gymnosperm wood and needles with moss would be able to explain the observed river DOM

636 values of Pn-yields, $\mathrm{P} / \mathrm{V}$ and $\mathrm{Pn} / \mathrm{P}$, while a mixture with angiosperm wood and leaves would not.

637 Based on the $\mathrm{S} / \mathrm{V}, \mathrm{C} / \mathrm{V}, \mathrm{P} / \mathrm{V}$, and $\mathrm{Pn} / \mathrm{P}$ ratios it seems reasonable to assume that most of the

638 Arctic River DOM during peak flow is derived from relatively fresh vegetation. We would thus

639 expect a strong relationship between biomass and DOM export in the different watersheds under

640 undisturbed conditions (no forest fires). The Lena and Yenisei, which have by far the highest

641 lignin discharge (and the lowest $\mathrm{S} / \mathrm{V}$ and $\mathrm{C} / \mathrm{V}$ values), also have the largest fraction of boreal

642 forests within their watersheds (Table 1). A positive relationship exists between the annual lignin

643 export from the rivers and the percentage of forest cover in the respective watersheds (data not

644 shown). A compilation for boreal forest biomass, based on new satellite data (Envisat) is

645 currently under way and expected to be available sometime in 2012 (Schmullius et al. pers.

646 Comm.). DOM collected from a boreal forest lake (Ouellet et al., 2009) resembles the peak flow

647 river DOM very closely (Fig. 6AB), also suggesting that boreal forest vegetation is a dominant

648 source of DOM for Arctic rivers during the snow-melt driven peak flow. Based on the observed

649 lignin monomer ratios (Fig 6AB) and the endmember values given in Table 4 we performed a

650 simple endmember mixing calculation (Ertel and Hedges, 1985) for the freshet in Lena and Ob,

651 representing the two rivers which had the least resemblance in terms of lignin monomer

652 composition, as well as for the low flow situation in the Yukon (as the most unique example

653 during winter). For this rough estimate we calculated the relative contribution of gymnosperms,

654 angiosperms, mosses, soil, and peat based on each of the following lignin parameters, $\mathrm{S} / \mathrm{V}, \mathrm{C} / \mathrm{V}$,

$655 \mathrm{P} / \mathrm{V}$, and $\mathrm{Pn} / \mathrm{P}$. The relative contribution of each source was adjusted in equations 1-4 until all 4

656 equations returned similar results to the measured river values. Based on such estimate, the Lena

657 freshet-DOM signal could be derived predominantly (70\%) from gymnosperm vegetation and 
658 fresh litter with lesser contributions from angiosperm vegetation and litter (15\%), and mosses 659 and peat (13\%). The lignin composition of freshet-DOM in the $\mathrm{Ob}$ on the other hand, could be 660 comprised of $45 \%$ gymnosperm, $23 \%$ angiosperm, and $25 \%$ moss and peat contributions. The 661 base-flow situation is quite different and more challenging to describe in terms of DOM sources 662 because the origin of groundwater, which dominates the river flow in late winter in these rivers, 663 is poorly understood. DOM transported during that time has obviously penetrated the deeper soil 664 layers and experienced sorption/desorption and degradation processes which changes the lignin 665 fingerprint. In addition, base-flow DOM contributes only about $5 \%$ to the annual lignin 666 discharge and might represent more localized sources (e.g. wetlands, taliks; Gibson pers. com.).

667 In order to account for the lignin composition found in Yukon and Ob base-flow DOM one 668 would need a mixture of approximately $1 / 3$ rd vegetation or litter (gymnosperm plus 669 angiosperm), $1 / 3$ rd soil and peat and about $1 / 3$ rd of an unidentified source with highly elevated 670 levels of p-hydroxybenzenes and p-coumaric acid. The unique lignin composition in base flow 671 DOM in Yukon and Ob was not represented in any of the endmembers identified in this study

672 (Table 4) but it obviously is characterized by very high contributions of p-hydroxybenzenes 673 which are most abundant in mosses and peat.

674 The use of endmembers derived from different plants (Hedges and Mann, 1979) for 675 describing the sources of river DOM based on lignin monomer ratios is not straightforward. A 676 shift in the lignin monomer ratios has been observed during leaching and sorption processes 677 (Hernes et al., 2007). Significant differences in the lignin composition have also been observed 678 between soil organic matter and the corresponding soil DOM fraction (Prokushkin and 679 Guggenberger pers. comm) as well as between leachates from litter, surface soils, and subsurface 680 soils (Kaiser et al., 2004). In addition to phase change effects, we need to consider diagenetic 
681 effects which become more important during the mid and especially during base flow conditions.

682 Some of the endmembers given in Table 4 are from leachates of plant material but the influence

683 of sorption/desorption and degradation are still poorly constrained in our endmembers, like

684 moss- and peat-derived DOM. The estimates given above are therefore rough estimates useful

685 only for providing order of magnitude proportions. In order to understand the DOM sources

686 during base flow conditions we need to develop a better understanding of the influence of

687 leaching, sorption, desorption, and degradation on the lignin phenol composition of DOM in the

688 different watersheds. In the property-property plots (Fig. 6AB) we compiled some of the

689 available data on endmembers and put them in perspective to the river DOM values.

690 Sorption and desorption becomes more important in the late summer, fall, and winter as a

691 larger fraction of river water comes from groundwater (Gibson and Prowse, 2002; Gibson pers.

692 com.) and has therefore percolated through the soils. Hence, most of the low flow DOM has been

693 in contact with different surface and subsurface soil layers. Typically, DOM in subsurface soils

694 has a lower lignin yield than surface soils (Kaiser et al., 2004). Soil studies in the Yenisei

695 watershed have directly shown that soil organic matter is different from soil DOM with a rapid

696 decline in lignin yields, and an increase in $\mathrm{S} / \mathrm{V}$ and $\mathrm{C} / \mathrm{V}$ ratios, especially in DOM from

697 subsurface soils (Prokushkin et al. in prep.). These trends are consistent with what we see in

698 most rivers as they transition from snowmelt driven surface run-off to groundwater driven base

699 flow. The general shift to lower lignin yields, higher S/V and C/V ratios along with elevated

700 values of other lignin based diagenetic indicators (CAD/FAD; 3,5Bd/V; $/ \mathrm{V})$, and DOM age

701 between peak flow and low flow indicate that we are either seeing changes in the relative

702 contribution from different DOM sources, differences in the relative contribution of DOM that

703 has undergone processing either in the terrestrial environment or during transport, or a 
704 combination of the two. P/V ratios were particularly elevated during base flow in the Yukon and

705 the Ob, which are also the two rivers with the oldest base flow DOM (Raymond et al., 2007).

706 The only sources that could explain such high P/V values are mosses, soils, and peat bogs. The

707 concentrations of $\mathrm{p}$-hydroxybenzenes are significantly correlated to the $\mathrm{Pn} / \mathrm{P}$ ratio, which never

708 drops below 0.22 . This argues against a significant contribution of p-hydroxybenzenes from the

709 conversion of protein or carbohydrates during $\mathrm{CuO}$ oxidation. In addition, proteins and

710 carbohydrates are typically not retained by the C18 resins used in this study to isolate lignin from

711 the river samples. We think that the abundance of p-hydroxybenzenes in the river samples is a

712 valid indicator for a significant moss and peat contribution to the DOM pool. Pn-yields are

713 elevated in all rivers throughout the year, but particularly during base flow in Ob and Yukon.

714 During freshet mosses are the most likely reason for elevated Pn-yields, while peat bogs and

715 wetlands will become more important Pn sources during base flow.

716 A recent study (Jensco et al., 2009) pointed to the importance of hydrologic connectivity

717 of a stream to its watershed when it comes to solute transport. This connectivity changes during

718 seasons, with high connectivity during freshet (including hill slopes, valley bottoms, and

719 lowlands) and low connectivity during winter low flow (hill slopes are largely disconnected)

720 conditions. Translated to the large rivers studied here it would mean that during the freshet most

721 of the watershed is hydrologically connected to the streams and therefore organic matter can

722 derive from all parts of the watershed including hill slopes where most of the boreal forest

723 biomass resides. During low flow conditions large parts of the watershed are isolated from the

724 stream network, especially in watersheds with mountainous regions. This restricts organic matter

725 sources to valley bottoms and lowlands, including wetlands. The lignin signature we found in the

726 rivers indicates that such a shift is most pronounced in the $\mathrm{Ob}$ and Yukon. While in the $\mathrm{Ob}$ 
727 watershed one can expect a significant contribution from mosses and peat because it contains the 728 largest peat bog system on earth, the shift in the Yukon River is less obvious. We think the

729 reason we see a strong shift in the Yukon River has to do with the abundance of mountainous

730 regions and lowland wetlands in the watershed and it seems that during low flow in winter much

731 of the water and organic matter is contributed by those lowland wetlands. This does not agree

732 with the satellite based vegetation data presented in Table 1, but would be consistent with a

733 recent study stating that $30 \%$ of the Yukon watershed are covered by low lying wetlands

734 (O’Donnell et al., 2010). The existing vegetation maps based on vegetation continuous field data 735 (VCF-MODIS) or global land cover (GLC) data are not specific enough to completely resolve 736 watershed differences and don't always agree with ground observations. Improved maps for 737 watershed vegetation are needed to better understand carbon transport in a changing climate.

738 Due to the many poorly constrained factors influencing the lignin composition during

739 base flow we feel it is premature to assign exact percentages to the different potential DOM

740 sources for each river during the different seasons beyond the approximate breakdown for the

741 most extreme situations given above. The main reason is that each watershed differs in terms of

742 climate, vegetation, land use, topography, and hydrologic connectivity, and that sources and

743 hydrology change in a different way in each watershed during the seasons. In general terms it

744 appears that soil and peat DOM from wetlands contribute a dominant portion to the river DOM

745 pool during low flow periods, but one has to keep in mind that only about $5 \%$ of the annual

746 lignin load is discharged during the 6 month of low flow. During freshet, which contributes

$747 \sim 75 \%$ of the annual lignin load, vegetation and fresh litter from boreal forests seems to be by far 748 the dominant source of river DOM. 


\subsection{Fate of river DOM in the Arctic Ocean}

751 The input of terrigenous DOM to the Arctic Ocean has a strong geographic and seasonal bias.

752 The Eurasian shelves receive $\sim 90 \%$ of the total annual lignin discharge, while the Alaskan and

753 Canadian shelves only receive $10 \%$ of the annual Arctic lignin load. Additionally, about $75 \%$ of

754 the annual load is discharged during freshet. This uneven input has important implications for the

755 distribution of lignin and our interpretation of its fate in the Arctic Ocean. After discharge, the

756 general path of the bulk of terrigenous DOM in the Eurasian Arctic follows the Eurasian shelf to

757 the East Siberian Sea where it enters the open Arctic Ocean in the Transpolar Drift and crosses

758 the central Arctic towards Fram Strait and the Canadian Archipelago (Opsahl et al., 1999; Guay

759 et al., 1999; Amon et al., 2003; Morrison et al., 2012; Amon et al. in prep.). Because of the

760 strong seasonal discharge variation the distribution of terrigenous DOM will not be

761 homogeneous along that path but rather reflect patches of elevated terrigenous DOM. A large

762 proportion of the terrigenous DOM from North American rivers is transported east in the

763 Alaskan Coastal Current and leaves the Arctic through the Canadian Archipelago (Macdonald et

764 al., 2002). The smaller input of lignin to the Canada Basin is reflected in much lower lignin

765 concentrations found in its surface waters, while the Transpolar Drift surface waters are

766 characterized by very high lignin concentrations (Amon et al. in prep).

767 Terrestrial DOM has been used as a tracer of water masses in the Arctic Ocean (Guay et

768 al., 1999; Amon et al., 2003; Benner et al., 2005; Walker et al., 2009; Gueguen et al., 2011) and

769 its fate is therefore of interest to the wider Arctic oceanographic community. During the transit

770 from the watersheds to the Arctic Ocean exit gateways a portion of the terrigenous DOM will be

771 degraded, reducing the strong seasonal variation. The amount of degradation has been a matter of

772 debate over the last few years but the rapid seasonal changes observed in river DOM 
773 concentration and composition indicate very strong temporal variability in sources (Fig. 3 and 5).

774 For some lignin parameters, like the lignin yield, the shift in concentrations is very rapid $(<1$

775 month) and it is therefore very difficult to determine a representative endmember concentration

776 for Arctic rivers, especially when including the estuarine mixing zone. Early studies (Cauwet et

777 al., 1996; Kattner et al., 1999; Koehler et al., 2003; Amon, 2004) have reported the conservative

778 behavior of DOC during estuarine mixing in the late summer. More recent studies on the

779 degradability of DOM in small Arctic rivers (Kawahigashi et al., 2004; Holmes et al., 2008) have

780 indicated that a substantial fraction of the soil DOM and freshet DOM in the rivers is actually

781 degradable on a time scale of a few weeks to months. Both studies indicate that $30-40 \%$ can be

782 degraded during incubations with the bulk of the degradation happening during the first few

783 weeks. Independent estimates for degradable DOC can be derived indirectly by comparing the

784 peak flow DOC concentrations, determined in the PARTNERS Project, to theoretical river

785 endmember DOC values derived from earlier studies in the $\mathrm{Ob}$ and Yenisei estuaries (Kara Sea;

786 Koehler et al., 2003). However, to derive reasonable endmembers from the salinity-DOC

787 relationships we corrected the DOC data for dilution caused by sea-ice melt (Figure 7). This is

788 accomplished by using the existing estimates for sea ice melt, based on salinity and stable

789 oxygen isotope values determined for each sample (Bauch et al., 2003). This correction increases

790 DOC values in the low salinity regions resulting in a steeper slope of the linear regression,

791 relating salinity to DOC concentrations, and therefore elevated theoretical river endmember

792 concentrations (Fig. 7). Based on the corrected DOC values, the theoretical endmembers are 710

$793 \mu \mathrm{M}$ DOC for the Ob and $736 \mu \mathrm{M}$ DOC for the Yenisei (Fig. 7) with corresponding freshet DOC

794 concentrations of $925 \mu \mathrm{M}$ for the $\mathrm{Ob}$ and $1120 \mu \mathrm{M}$ DOC for the Yenisei (Amon unpubl. data).

795 Because the samples from the quantitatively most important rivers were collected $>600 \mathrm{~km}$ 
upstream of the confluence with the Arctic Ocean (a time span of several weeks) a loss of lignin 797 and terrigenous DOC in general could have occurred which could significantly lower the DOC 798 input estimates to the Arctic Ocean.

Another argument in favor of rapid removal of freshet DOM can be found in the strong

800 difference between the Mackenzie River and the other rivers. The Mackenzie seems to lack the

801 large spike in lignin phenols (with young ages) during freshet. Because there is no logical reason

802 to assume that the Mackenzie watershed would not produce the same type and amount of young,

803 vegetation-derived DOM during freshet we propose that the lack of the spring peak can be

804 explained by rapid removal during DOM transport from the watershed to the downstream

805 sampling station. As explained above the Mackenzie watershed is unique in terms of the

806 abundance of large lakes and other water bodies (Table 1), which increases the residence time or

807 transit time of DOM within the watershed during which a significant fraction of labile

808 components can be removed.

809 The reason for the differences between the bioavailability of freshet DOM and mid flow

810 DOM must have to do with the difference in the chemical composition. Freshet DOM is

811 characterized by very high lignin yields with elevated acid/aldehyde ratios indicating freshly

812 leached vascular plant DOM. It is possible that a significant fraction of the plant leachates during

813 spring freshet are free lignin phenols and ligno-cellulose compounds (Prokushkin et al., 2007),

814 rather than structural lignin phenols, and the free lignin phenols could be degraded faster. This

815 could explain the significant, but short-lived spike in lignin phenol yields during freshet and

816 lignin yield could be an indicator for riverine DOM bioavailability, analogous to what has been

817 observed for the neutral sugar yield (Cowie and Hedges, 1982; Skoog and Benner, 1997; Amon

818 et al., 2001). If these assumptions are correct a significant portion of freshet DOM could be 
819 removed before passing the estuaries into the Arctic Ocean, which will affect our estimates for

820 input, distribution, export, and processing of terrestrial DOM in the Arctic Ocean.

\section{5. CONCLUSIONS}

823 The lignin phenol and p-hydroxybenzene composition of Arctic river DOM indicate a strong

824 seasonal change in DOM sources with fresh vegetation, mainly boreal forests, dominating during

825 spring freshet and contributing $75 \%$ of the annual lignin load, while base flow DOM contains a

826 significant fraction of peat/moss derived DOM (>30\%). DOM from different watersheds can be

827 distinguished from each other reflecting the variations in climate, vegetation, topography, and

828 hydrologic connectivity in the watersheds. All rivers except the Mackenzie showed comparable

829 patterns in lignin signatures with strong relationships to the ${ }^{14} \mathrm{C}$-age of DOM. With a warming

830 climate, increased precipitation and hydrologic connectivity, and a northward extension of the

831 boreal forests, one can expect an increase in DOM transport to the Arctic Ocean in the future.

832 During spring freshet such an increase will be caused by more biomass production in the

833 watersheds. For the base flow conditions increasing hydrologic connectivity in the high latitude

834 watersheds could be the key parameter for increasing DOM fluxes during that time. Increased

835 frequency of forest fires, on the other hand, would decrease the biomass in the watersheds and as

836 a consequence decrease the DOM export. Our data suggest that current descriptions of watershed

837 characteristics, especially the distribution of vegetation in these large watersheds could be

838 improved in terms of forest cover and wetland contributions.

839 DOC input to the Arctic Ocean has a very high temporal and geographical variability

840 with a strong bias towards the large Eurasian Rivers and the freshet period. The large and rapid

841 temporal variability paired with complex estuarine DOC dynamics (ice formation and melt) 
842 make it difficult to choose representative river DOC input estimates which have a

843 disproportionate effect on our understanding of DOC export and fate in the Arctic Ocean.

\section{REFERENCES}

846 Abaimov A.P. (2010) Geographical distribution and genetics of Siberian Larch species. In:

847 Permafrost ecosystems: Siberian Larch forests (Eds. Osawa A., Zyryanova O.A., 848 Matsuura Y., Kajimoto T., Wein R.W.) Springer. NY. pp. 41-58.

849 Amon R. M. W., Fitznar H.-P., Benner R. (2001) Linkages among the bioreactivity, chemical composition, and diagenetic state of marine dissolved organic matter. Limnol. Oceanogr. 46, 287-297.

852 Amon RMW. (2004) The role of dissolved organic matter for the organic carbon cycle in the Arctic Ocean. In: Stein R., MacDonald R. (editors.) The organic carbon cycle in the

Amon R. M. W., Budeus G., Meon B. (2003) Dissolved organic carbon distribution and origin in the Nordic Seas: Exchanges with the Arctic Ocean and the North Atlantic. J. Geophys. Res. 108 (C7, 3221): doi:10.1029/2002JC001594.

Amon R. M. W. and Meon B. (2004) The biogeochemistry of dissolved organic matter and nutrients in two large Arctic estuaries and potential implications for our understanding of the Arctic Ocean System. Marine Chemistry 92, 311-330.

861 Bauch, D., Erlenkeuser H., Stanovoy V., Simstich J., Spielhagen R. F. (2003) Freshwater distribution and brine waters in the southern Kara Sea. Siberian river run-off in the Kara Sea. Stein R., Fahl K., Fütterer D. K., Galimov E. M. and Stephanets O. V. Amsterdam, Elsevier. 6, 73-91. 
865 Benner R., Weliky K., Hedges J. I. (1990) Early diagenesis of mangrove leaves in a tropical estuary - molecular-level analyses of neutral sugars and lignin-derived phenols. Geochimica Et Cosmochimica Acta 54, 1991-2001.

Benner R. and Opsahl S., (2001) Molecular indicators of the sources and transformations of dissolved organic matter in the Mississippi River plume. Organic Geochemistry 32(4),

Benner R., Benitez-Nelson B., Kaiser K., and Amon R. M. W. (2004) Export of young terrigenous dissolved organic carbon from rivers to the Arctic Ocean. Geophysical Research Letters 31, L05305, doi:10.1029/2003GL019251

Benner R., Louchouarn P. and Amon R. M. W., 2005. Terrigenous dissolved organic matter in the Arctic Ocean. Global Biogeochemical Cycles 19, GB2025, doi:10.1029/2004GB002398

Benner R. and Kaiser K. (2010) Biological and photochemical transformations of amino acids and lignin phenols in riverine dissolved organic matter. Biogeochemistry 102, 209-222.

882 Breckle S. (2002) Walter's vegetation of the Earth. Berlin, Heidelberg, Springer.

883 Cauwet G., and Sidorov I. (1996) The biogeochemistry of Lena River: Organic carbon and nutrients distribution. Marine Chemistry 53, 211-227.

885 Cole J. J., Prairie Y. T., Caraco N. F., McDowell W. H., Tranvik L. J., Striegl R. G., Duarte C. 886 M., Kortelainen P., Downing J. A., Middelburg J. J. and Melack . (2007) Plumbing the 
global carbon cycle: Integrating inland waters into the terrestrial carbon budget. Ecosystems 10(1), 171-184.

Cooper L. W., Benner R., McClelland J. W., Peterson B. J., Holmes R. M., Raymond P. A., Hansell D. A., Grebmeier J. M., and Codispotti L. A. (2005) Linkages among runoff, dissolved organic carbon, and the stable oxygen isotope composition of seawater and other water mass indicators in the Arctic Ocean. J. Geophys. Res. 110, G02013, doi:10.1029/2005JG000031, 2005.

Cooper L. W., McClelland J. W., Holmes R. M., Raymond P. A., Gibson J. J., Guay C. K. and Peterson B. J. (2008) Flow-Weighted values of runoff tracers (d18O, DOC, Ba, alkalinity) from the six largest Arctic rivers. Geophys. Res. Lett. 35. L18606, doi:10.1029/2008GL035007

Cowie G. L. and Hedges J. I. (1984). Carbohydrate sources in a coastal marine environment. Geochimica et Cosmochimica Acta 48, 2075-2087.

Ertel J. R. and Hedges J. I. (1984) The lignin component of humic substances distribution among soil and sedimentary humic, fulvic, and base-insoluble fractions. Geochimica Et Cosmochimica Acta 48, 2065-2074.

Ertel J. R., Caine J. M. and Thurman E. M. (1993) Biomarker compounds as source indicators for dissolved fulvic-acids in a bog. Biogeochemistry 22(3), 195-212.

Ertel J. R., Hedges J. I., Devol A., Richey J. E. and de Nazare Goes Ribeiro M. (1986) Dissolved humic substances of the Amazon River system. Limnology and Oceanography 31(4): $139-154$.

Finlay J., Neff J., Zimov S., Davydova A., and Davydov S. (2006) Snowmelt dominance of dissolved organic carbon in high-latitude watersheds: Implications for characterization 
and flux of river DOC. Geophysical Research Letters 33, L10401, doi:10.1029/2006GL025754

912 Gibson J. J and Prowse T. D., (2002) Stable isotopes in river ice: identifying primary over-winter 913 streamflow signals and their hydrological significance. Hydrological Processes 16, 873$914 \quad 890$.

915 Goñi M. A. and Hedges J. I. (1992) Lignin Dimers - Structures, Distribution, and Potential 916 Geochemical Applications. Geochimica Et Cosmochimica Acta, 56(11), 4025-4043.

917 Goñi M. A. and Hedges J. I. (1995) Sources and Reactivities of Marine-Derived Organic-Matter 918 in Coastal Sediments as Determined by Alkaline Cuo Oxidation. Geochimica Et $919 \quad$ Cosmochimica Acta, 59(14), 2965-2981.

920 Goñi M. A. and Montgomery, S. (2000) Alkaline CuO oxidation with a microwave digestion 921 system: Lignin analyses of geochemical samples. Analytical Chemistry, 72(14): 3116$922 \quad 3121$.

923 Goni M. A., Yunker M. B., Macdonald R. W., and Eglington T. I. (2000) Distribution and 924 sources of organic biomarkers in arctic sediments from the Mackenzie River and $925 \quad$ Beaufort Shelf. Marine Chemistry 71, 23-51.

926 Goni M. A., Yunker M. B., Macdonald R. W., and Eglington T. I. (2005) The supply and 927 preservation of ancient and modern components of organic carbon in the Canadian 928 Beaufort Shelf of the Arctic Ocean. Marine Chemistry 93, 53-73.

929 Gordeev V. V. (2006) Fluvial sediment flux to the Arctic Ocean. Geomorphology 80, $930 \quad 94-104$.

931 Gordeev V. V., Rachold V., and Vlasova I. E. (2004) Geochemical behaviour of 932 major and trace elements in suspended particulate material of the Irtysh river, the 

main tributary of the Ob river, Siberia. Applied Geochemistry 19, 593-610.

934 Granskog M. A., Stedmon C. A., Dodd P. A., Amon R. M. W., Pavlov A., Hansen K. (2012) Fate 935 of terrestrial colored dissolved organic matter in the Arctic Ocean: exported or removed? 936 Geophysical Research Letters (submitted)

937 Guay, C. K. H., McLaughlin F. A., and Yamamoto-Kawai M. (2009) Differentiating fluvial 938 components of upper Canada Basin waters on the basis of measurements of dissolved 939 barium combined with other physical and chemical tracers, J. Geophys. Res., 114, $940 \quad$ C00A009, doi:10.1029/2008JC005099.

941 Guéguen, C., McLaughlin F. A., Carmack E. C., Itoh M., Narita H., Nishino S. (2011) The 942 nature of colored dissolved organic matter in the southern Canada Basin and East 943 Siberian Sea. Deep Sea Res. II doi:10.1016/j.dsr2.2011.05.004

944 Guggenberger G. und Zech W. (1994) Composition and dynamics of dissolved carbohydrates 945 and lignin-degradation products at spruce forest sites, Bavaria, Germany. Soil Biol. $946 \quad$ Biochem. 26, 19-27.

947 Guo L. D., and Macdonald R. W. (2006) Source and transport of terrigenous organic matter in the upper Yukon River: Evidence from isotope (delta C-13, Delta C-14,

949 and delta N-15) composition of dissolved, colloidal, and particulate phases.

$950 \quad$ Global Biogeochemical Cycles 20: DOI:10.1029/2005GB002593

951 Hedges J. I. and Parker P. L. (1976) Land-derived organic matter in surface sediments from the 952 Gulf of Mexico. Geochimica et Cosmochimica Acta 40 1019-1029.

953 Hedges J. I. and Mann D. C. (1979) Characterization of Plant-Tissues by Their Lignin 954 Oxidation-Products. Geochimica et Cosmochimica Acta 43(11), 1803-1807. 
955 Hedges J. I. and Ertel J. R. (1982) Characterization of lignin by gas capillary chromatography of cupric oxide oxidation products. Analytical Chemistry 54, 174-178.

957 Hedges J. I., Ertel J. R. and Leopold E. B. (1982) Lignin geochemistry of a Late Quaternary

958 sediment core from Lake Washington. Geochimica et Cosmochimica Acta 46(10), 1869-

9591877.

960 Hedges J. I., Keil R. G. and Benner R. (1997) What happens to terrestrial organic matter in the ocean? Organic Geochemistry, 25(5/6), 195-212.

962 Hedges J. I., Mayorga E., Tsamakis E., McClain M.E., Aufdenkampe A.K., Quay P.D., Richey J.E., Benner R., Opsahl S. (2000) Organic matter in Bolivian tributaries of the Amazon River: A comparison to the lower mainstream. Limnology and Oceanography 45(7), 1449-1466.

Hernes P. J. and Benner R. (2002) Transport and diagenesis of dissolved and particulate terrigenous organic matter in the North Pacific Ocean. Deep-Sea Research Part I-Oceanographic Research Papers 49, 2119-2132.

972 Holmes R. M., McClelland J. W., Peterson B. J., Shiklomanov I. A., Shiklomanov A. I., 973 Zhulidov A. V., Gordeev V. V., and Bobrovitskaya N. N. (2002) A circumpolar 974 perspective on fluvial sediment flux to the Arctic Ocean. Global Biogeochemical Cycles 16, 1098, doi:10.1029/2001GB001849. 
976 Holmes R. M., McClelland J. W., Raymond P. A., Frazer B. B., Peterson B. J., Stieglitz M.

977 (2008) Lability of DOC transported by Alaskan rivers to the Arctic Ocean. Geophys. Res. $978 \quad$ Lett. 35, L03402, doi:10.1029/2007GL032837.

979 Holmes R. M., McClelland J. W., Peterson B. J., Tank S. E., Bulygina E., Eglinton T. I., 980 Gordeev V. V., Gurtovaya T. Y., Raymond P. A., Repeta D. J., Staples R., Striegl R. G., 981 Zhulidov A. V., and Zimov S. A. (2011) Seasonal and annual fluxes of nutrients and 982 organic matter from large rivers to the Arctic Ocean and surrounding seas. Estuaries and $983 \quad$ Coasts, DOI 10.10007/s12237-011-9386-6.

984 Houel S., Louchouarn P., Lucotte M., Canuel R. and Ghaleb B. (2006) Translocation of soil 985 organic matter following reservoir impoundment in boreal systems: Implications for in 986 situ productivity. Limnology and Oceanography 51, 1497-1513.

987 Jencso K. G., McGlynn B. L., Gooseff M. N., Wondzell S. M., Bencala K. E. and Marshall L. A. 988 (2009) Hydrologic connectivity between landscapes and streams: Transferring reach- and 989 plot-scale understanding to the catchment scale, Water Resour. Res., 45, W04428, 990 doi:10.1029/2008WR007225.

991 Kaiser K., Guggenberger G. and Haumaier L. (2004) Changes in dissolved lignin derived 992 phenols, neutral sugars, uronic acids, and amino sugars with depth in forested Haplic 993 Arenosols and Rendzic Leptosols. Biogeochemistry 70, 135-151.

994 Kattner G., Lobbes J., Fritznar H. P., Engbrodt R., Lara R. J. (1999) Tracing dissolved organic 995 substances and nutrients from the Lena River through Laptev Sea (Arctic). Mar. Chem. $996 \quad \mathbf{6 5}, 25-39$. 
997 Kawahigashi M., Kaiser K., Kalbitz K., Rodionov A. and Guggenberger G. (2004) Dissolved

998

999

1000

1001

1002

1003

1004

1005

1006

1007

1008

1009

1010

1011

1012

1013

1014

1015

1016

1017

1018

1019

organic matter in small streams along a gradient from discontinuous to continuous permafrost. Global Change Biology 10, 1576-1586.

Kawahigashi M., Kaiser K., Rodionov A. and Guggenberger G. (2006) Sorption of dissolved organic matter by mineral soils of the Siberian forest tundra. Global Change Biology 12, 1868-1877.

Koehler H., Meon B., Gordeev V. V., Spitzy A. and Amon R. M. W. (2003) Dissolved organic matter (DOM) in the estuaries of $\mathrm{Ob}$ and Yenisei and the adjacent KaraSea, Russia. Proceedings in Marine Science 6, 281-309.

Kremenetski K. V., Velichko A. A., Borisova O. K., MacDonald G. M., Smith L. C., Frey K. E. and Orlova L. A. (2003) Peatlands of the Western Siberian lowlands: Current knowledge on zonation, carbon content and Late Quaternary history. Quaternary Science Reviews 22, 703-723.

Kuo L.-J., Herbert B. E. and Louchouarn P. (2008a) Can levoglucosan be used to characterize and quantify char/charcoal black carbon in environmental media? Organic Geochemistry 39, 1466-1478.

Kuo L.-J., Louchouarn P. and Herbert B. E. (2008b) Fate of CuO-derived lignin oxidation products during plant combustion: Application to the evaluation of char inputs to soil organic matter. Organic Geochemistry 39, 1522-1536.

Lobbes J. M., Fitznar H. P. and Kattner G. (2000) Biogeochemical characteristics of dissolved and particulate organic matter in Russian rivers entering the Arctic Ocean. Geochimica Et Cosmochimica Acta 64, 2973-2983.

Louchouarn P., Opsahl S. and Benner R. (2000) Isolation and quantification of 
dissolved lignin from natural waters using solid-phase extraction and GC/MS. Analytical Chemistry 72, 2780-2787

1022 Louchouarn P., Amon R. M. W., Duan S., Pondell C., Seward S. M. and White N. (2010) 1023 Analysis of lignin-derived phenols in standard reference materials and dissolved organic

Macdonald, R. W., McLaughlin F. A. and Carmack E. C. (2002) Freshwater and its sources during the SHEBA drift in the Canada Basin of the Arctic Ocean. Deep-Sea Research I. 49(10), 1769-1785.

McClelland J. W., Holmes R. M., Peterson B. J., Amon R. M. W., Brabets T., Cooper L., Gibson J., Gordeev V.V., Guay C., Milburn D., Raymond P.A., Shiklomanov I., Staples R., Striegl R., Zhulidov A.T., Gurtovaya T., Zimov S. (2008) Development of a Pan-Arctic Database for River Chemistry. EOS 89(24), 217-218.

McGuire A. D., Anderson L. A. Christensen T.R., Dallimore S., Guo L., Hayes D.J., Heimann M., Lorenson T.D., Macdonald R.W., Roulet, N. (2009) Sensitivity of the carbon cycle in the Arctic to climate change. Ecological Monographs 79(4), 523-555.

McGuire A. D., Macdonald R. W., Schuur E. A. G., Harden J. W., Kuhry P., Hayes D. J., Christensen T. R., and Heimann M. (2010) The carbon budget of the northern cryospere region. Current opinion in Environmental sustainability 2, 231-236.

Morison J., Kwok R., Peralta-Ferriz C., Alkire M., Rigor I., Andersen R. and Steele, M., 2012. Changing Arctic Ocean freshwater pathways. Nature 481, 66-70.

Neff J. C., Finlay S. A., Zimov S. P., Davydov J. J. Carrasco E., Schuur A. G. and Davydova A. I. (2006) Seasonal changes in the age and structure of dissolved organic carbon in 
Siberian rivers and streams. Geophysical Research Letters 33, L23401, doi:

1044 Opsahl S. and Benner R. (1995) Early diagenesis of vascular plant-tissues - lignin and cutin 1045 decomposition and biogeochemical implications. Geochimica Et Cosmochimica Acta 59, $1046 \quad 4889-4904$.

1047 Opsahl S. and Benner R. (1997) Distribution and cycling of terrigenous dissolved organic matter 1048 in the ocean. Nature 386, 480-482.

1049 Opsahl S. and Benner R. (1998) Photochemical reactivity of dissolved lignin in river and ocean $1050 \quad$ waters. Limnology and Oceanography 43, 1297-1304.

1051 Opsahl S., Benner R. and Amon R. M. W. (1999) Major flux of terrigenous dissolved 1052 organic matter through the Arctic Ocean. Limnology and Oceanography 44, $1053 \quad 2017-2023$.

1054 Ouellet J., Lucotte M. Teisserenc R., Paquet S., Canuel R. (2009) Lignin biomarkers as tracers of 1055 mercury sources in lakes water column. Biogeochemistry 94, 123-140.

1056 Peterson B. J., Holmes R. M., McClelland J. W., Vorosmarty C. J., Shiklomanov I. A., 1057 Shiklomanov A. I., Lammers R. B. and Rahmstorf S. (2002) Increasing river discharge to 1058 the Arctic Ocean. Science 298, 2171-2173.

1059 Peterson M. L., Lang S. Q., Aufdenkampe A. K. and Hedges J. I. (2003) Dissolved 1060 organic carbon measurement using a modified high-temperature combustion $1061 \quad$ analyzer. Marine Chemistry 81, 89-104.

1062 Prokushkin S. G., Abaimov A. P., Prokushkin A. S., Masyagina O. V. (2006) Biomass of ground 1063 floor vegetation and understory in larch forests of cryolythozone of Central Siberia. 
1064

1065

1066

1067

1068

1069

1070

1071

1072

1073

1074

1075

1076

1077

1078

1079

1080

1081

1082

1083

1084

1085

1086

Sibirskiy Ekologicheskiy zhurnal (Contemporary Problems of Ecology) 2, 131-139. (In Russian)

Prokushkin A. S., Gleixner G., McDowell W. H., Ruehlow S. and Schulze E.-D. (2007) Source and substrate-specific export of dissolved organic matter from permafrost-dominated forested watershed in central Siberia. Global Biogeochemical Cycles, 21, GB4003, doi: 10.1029/2007GB002938.

Prokushkin A. S., Pokrovsky O.S., Shirokova L. S., Korets M.A., Viers J., Prokushkin S. G., Amon R. M. W., Guggenberger G. and McDowell W.H. (2011) Sources and the flux pattern of dissolved carbon in rivers of the Yenisey basin draining the Central Siberian Plateau. Environ. Res. Lett. 6045212 (14pp) doi:10.1088/1748-9326/6/4/045212.

Qian J. G., and Mopper K. (1996). Automated high performance, high-temperature combustion total organic carbon analyzer. Analytical Chemistry 68, 3090-3097

Rachold, V. (1999) Major, trace and rare earth element geochemistry of suspended particulate material of east siberian rivers draining to the arctic ocean. In Land-ocean systems in the Siberian Arctic dynamics and history. Eds: Kassens, H., Bauch H.A., Dmitrenko I.A., Eicken H., Hubberten, H.W. Melles, M. Thiede, J., Timokhov, L.A.. Springer-Verlag, New York.

Rachold V., Eicken H., Gordeev V.V., Brigoriev M.N., Hubberten M.-W., Lisitzin A.P., Shevschenko V.P. and Schirrmeister L. (2004) Modern terrigenous organic carbon input to the Arctic Ocean. In: The organic carbon cycle in the Arctic Ocean. Eds: Stein, R. and Macdonald, R.W. pages 33-54.

Raymond P. A., McClelland J. W., Holmes R. M., Zhulidov A. V., Mull K., Peterson B. J., Striegl R. G., Aiken G. R. and Gurtovaya T. Y. (2007) Flux and age of dissolved organic 
carbon exported to the Arctic Ocean: A carbon isotopic study of the five largest arctic rivers, Global Biogeochem. Cycles 21: GB4011, doi:10.1029/2007GB002934.

Sanger L. J., Anderson J. M., Little D. and Bolger T. (1997) Phenolic and carbohydrate signatures of organic matter in soils developed under grass and forest plantations following changes in land use. European Journal of Soil Science 48, 311-317.

1092 Šantrůčková H., Bird M. I., Kalaschnikov Y. N., Grund M., Elhottová D., Šimek M., Grigoryev 1093 S., Gleixner G. (2003) Microbial characteristics of soils on a latitudinal transect in Siberia. Global Change Biology. 9, 1106-1117

1095 Schiff S. L., Aravena R., Trumbore S. E., Hinton M. Elgood J., R., Dillon P. J. (1997) Export of 1096 1097 DOC from forested catchments on the Precambrian Shield of Central Ontario: Clues from 13C and 14C, Biogeochemistry 36, 43-65

Smith L. C., MacDonald G. M., Velichko A. A., Beilman D. W., Borisova O. K., Frey K. E., 1099 Kremenetski K. V. \& Sheng Y. (2004) Siberian peatlands a net carbon sink and methane 1100 source since the early Holocene. Science 303, 353-356

1101 Spencer R. G. M., Aiken G. R., Butler K. D., Dornblaser M. M., Striegl R. G., Hernes P. (2009) 1102 Utilizing chromophoric dissolved organic matter measurements to derive export and

1105 Spencer R. G. M., Aiken G. R., Wickland K. P., Striegl R. G., Hernes P. J. (2008) Seasonal and 1106 spatial variability in dissolved organic matter quantity and composition from the Yukon 1107 river basin, Alaska. Global Biogeochem. Cycles. 22, GB4002, 1108 doi:10.1029/2008GB003231. 
1109 Skoog A. and Benner R. (1997) Aldoses in various size fractions of marine organic matter:

1110 Implications for carbon cycling. Limn. Oceanogr $\mathbf{4 2}$ 42, 1803-1813.

1111 Stedmon C. A., Amon R. M. W., Rhinehart A. J., Walker S. A. (2011) The supply and

1112 characteristics of colored dissolved organic matter (CDOM) in the Arctic Ocean. Marine

$1113 \quad$ Chemistry 124, 108-118. DOI:10.1016/j,marchem.2010.12.007

1114 Stolbovoi V. 2002. Carbon in Russian soils. Climatic Change 55, 131-156.

1115 Stolbovoi V., Fischer G., Ovenkin V.S. and Rozhkova S. (1998) Soils of Russia-correlated with

1116 the revised legend of the FAO soil map of the world, IIASA Interim Report IR-97-070,

1117 International Institute for Applied Systems Analysis, Laxenburg, Austria.

1118 Strasburger E., Noll F., Schenck H., Schimper A. F. W. Denffer D., Ziegler H., Ehrendorfer F.,

1119 Bresinsky A. (1983). Lehrbuch der Botanik. Stuttgard, Gustav Fisher Verlag. (in

1120 German).

1121 Striegl R. G., Aiken G. R., Dornblaser M. M., Raymond P. A., and Wickland K. P. (2005) A

1122 decrease in discharge-normalized DOC export by the Yukon River during summer

1123 through autumn. Geophysical Research Letters 32, DOI:10.1029/2005GL024413

1124 Striegl R. G., Dornblaser M. M., Aiken G. R., Wickland K. P. and Raymond P. A. (2007) Carbon

1125 export and cycling by the Yukon, Tanana, and Porcupine rivers, Alaska, 2001-2005.

$1126 \quad$ Water Resources Research 43, DOI:10.1029/2006WR005201

1127 Tareq S. M., Tanaka N. Keiichi O. (2004) Biomarker signature in tropical wetland: lignin phenol 1128 vegetation index (LPVI) and its implications for reconstructing the paleoenvironment.

$1129 \quad$ Science of the Total Environment 324, 91-103. 
1130 Tarnocai C., Canadell J. G., Schuur E. A. G., Kuhry P., Mazhitova G., Zimov S. (2009) Soil organic carbon pools in the northern circumpolar permafrost region. Global Biogeochemical cycles; 23, GB2023, doi:10.1029/2008GB003327.

1133 Teisserenc R., Lucotte M., Houel S., Carreau J. (2010) Integrated transfer of terrigenous organic matter to lakes at their watershed level: A combined biomarker and GIS analysis.

1135 Geochim. Cosmochim. Acta 74, 6375-6386.

1136 Timoney K. P., Laroi G. H., Zoltai S. C. and Robinson A. L. (1993) Vegetation

1137 communities and plant-distributions and their relationships with parent materials

1138 in the forest-tundra of northwestern Canada. Ecography 16, 174-188.

1139 Ugolini F. C., Reanier R. E., Rau, G. H., Hedges J. I. (1981) Pedological, isotopic, and

1140 geochemical investigations of the soils at the boreal forest and alpine tundra transition in $1141 \quad$ northern Alaska. Soil Science 131(6), 359-374.

1142 Wagner V. (1997) Analysis of a Russian Landscape map and landscape classification

1145 Walvoord M. A. and Striegl R. G. (2007) Increased groundwater to stream discharge from 1146 permafrost thawing in the Yukon River basin: Potential impacts on lateral export of 1147 carbon and nitrogen. Geophysical Research Letters 34, L12402, 1148 doi:10.1029/2007GL030216

1149 Walker S. A., Amon R. M. W., Stedmon C., Duan S. and Louchouarn P. (2009) The use of 1150 PARAFAC modeling to trace dissolved organic matter and fingerprint water masses in 1151 coastal Canadian Arctic surface waters. J. Geophys. Res., 114, G00F06, 1152 doi:10.1029/2009JG000990. 
1153 Williams C. J., Yavitt J. B., Kelman Wieder R. and Cleavitt N. L. (1998) Cupric oxide oxidation 1154 products of northern peat and peat-forming plants. Can. J. Bot 76, 51-62.

1155 Yang D. Q., Ye B. S. and Shiklomanov A. (2004) Discharge characteristics and changes over the 1156 Ob River watershed in Siberia. Journal of Hydrometeorology 5, 595-610.

1157 Yi Y., Gibson J. J., Hélie J., Dick T. A. (2010) Synoptic and time series stable isotope surveys of 1158 the Mackenzie River from Great Slave Lake to the Arctic Ocean, 2003-2006. Journal of $1159 \quad$ Hydrology 383, 223-232.

1160 Zhang T., Barry R. G. and Knowles K. (1999) Statistics and characteristics of permafrost 1161 and ground-ice distribution in the northern hemisphere. Polar Geography 23, $1162 \quad 132-154$

1163 Zhulidov A. V., Headley J. V., Robarts R. D., Nikanorov A. M. and Ischenko A. A. (1997) Atlas 1164 of Russian Wetlands: Biogeography and Metal Concentrations. Editor M. J. Brannen. 1165 Foreword R.G. Wetzel. National Hydrology Research Institute, Canada, 309 pp. 


\section{Figure legends}

Figure 1. Map of the watersheds of Ob, Yenisei, Lena, Kolyma, Yukon, and Mackenzie with the respective sampling locations indicated by a dot in the lower reaches of the rivers.

Figure 2. Seasonal discharge and lignin phenol concentrations (ug/L) in the 6 rivers between 2003 and 2007.

Figure 3. Average Lignin phenol concentrations and monomer ratios during the freshet, mid flow and base flow periods in the 6 rivers.

Figure 4. Relationship of lignin phenol concentrations to $\Delta^{14} \mathrm{C}(\% \mathrm{o})$ of dissolved organic carbon (DOC) in the six rivers.

Figure 5. Relationship of lignin phenol monomer ratios and lignin yield to $\Delta^{14} \mathrm{C}(\%)$ of dissolved organic carbon (DOC).

Figure 6. Property-property plots of lignin phenol monomer ratios (A, S/V versus C/V and B, phydroxybenzenes/V versus p-hydroxyacetophenone/P) in river dissolved organic matter (DOM) relative to different source materials. G-Gymnosperm wood, g-gymnosperm needles, Aangiosperm wood, a-angiosperm leaves, BFL-boreal forest lake, B-soil B horizon.

Figure 7. Distribution of DOC along the salinity gradient in the $\mathrm{Ob}$ and Yenisei estuaries relative to the measured freshet DOC values in the rivers (shown at 0 salinity). The difference between 
the theoretical riverine DOC endmember, based on a linear relationship of DOC and salinity, and the freshet DOC values is considered degradable DOC. However, during freshet the estuaries and coastal ocean is still frozen and the massive discharge of relatively warm riverwater will result in significant sea ice melt which dilutes the DOC concentrations. In order to correct for this dilution we estimated the amount of sea ice melt based on stable oxygen isotope values of water (Bauch et al. 2003) measured in the same samples as DOC. Stable oxygen isotopes of water along with salinity can be used in mass balance equations to calculate the contribution of river water, sea ice melt, and sea water, respectively (Bauch et al. 2003). Correcting for sea ice melt increases the DOC concentration. The same approach can be used to correct for the influence of brine, produced in the previous winter, which has the opposite effect on DOC concentrations. Linear regression used to estimate the theoretical endmembers are shown for both the uncorrected and the corrected DOC data set. The uncertainty for theoretical endmembers was $\pm 27.9 \mu \mathrm{M}$ DOC for the Ob River and $\pm 13.5 \mu \mathrm{M}$ DOC for the Yenisey River. 


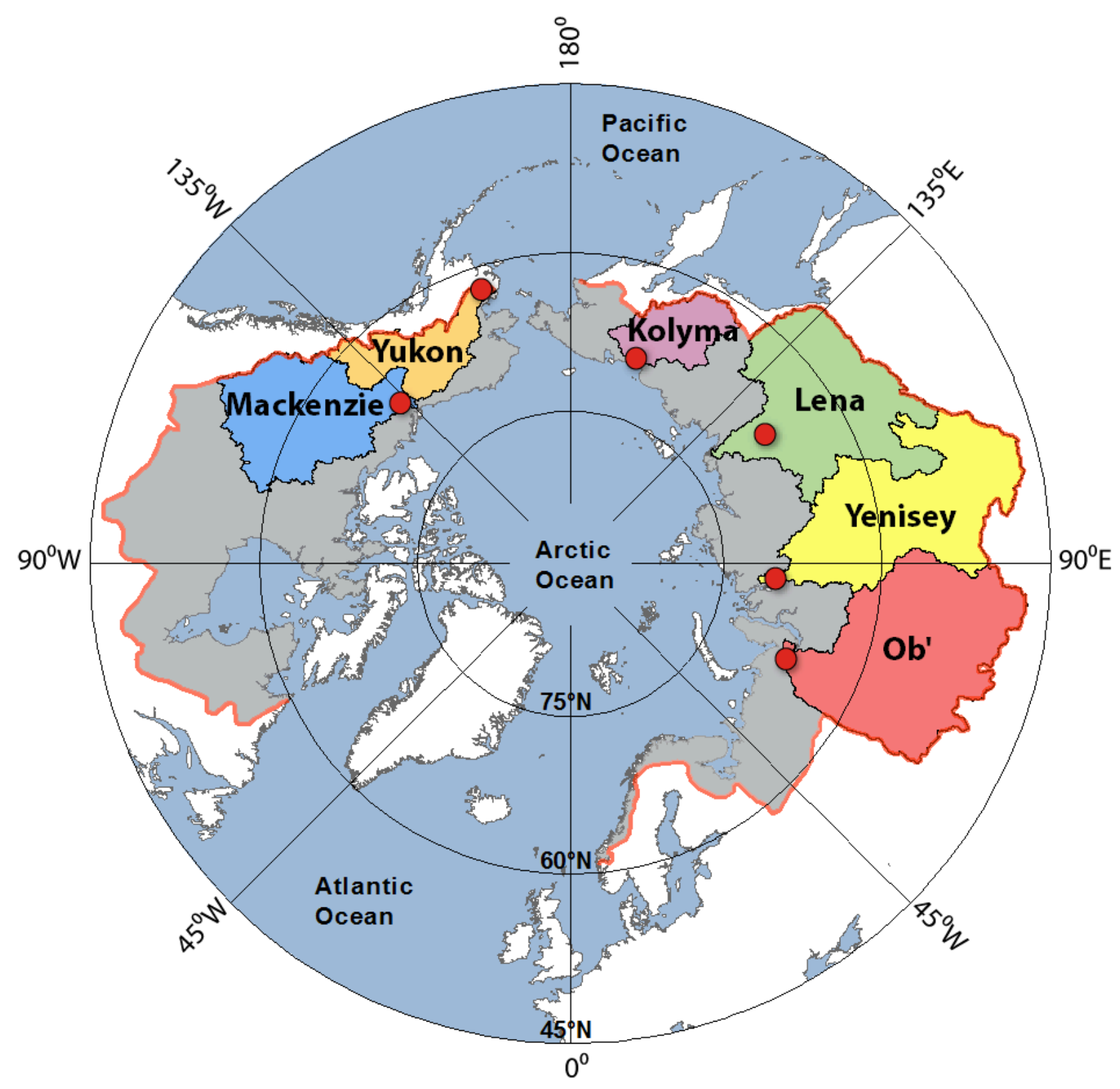

Figure 1 

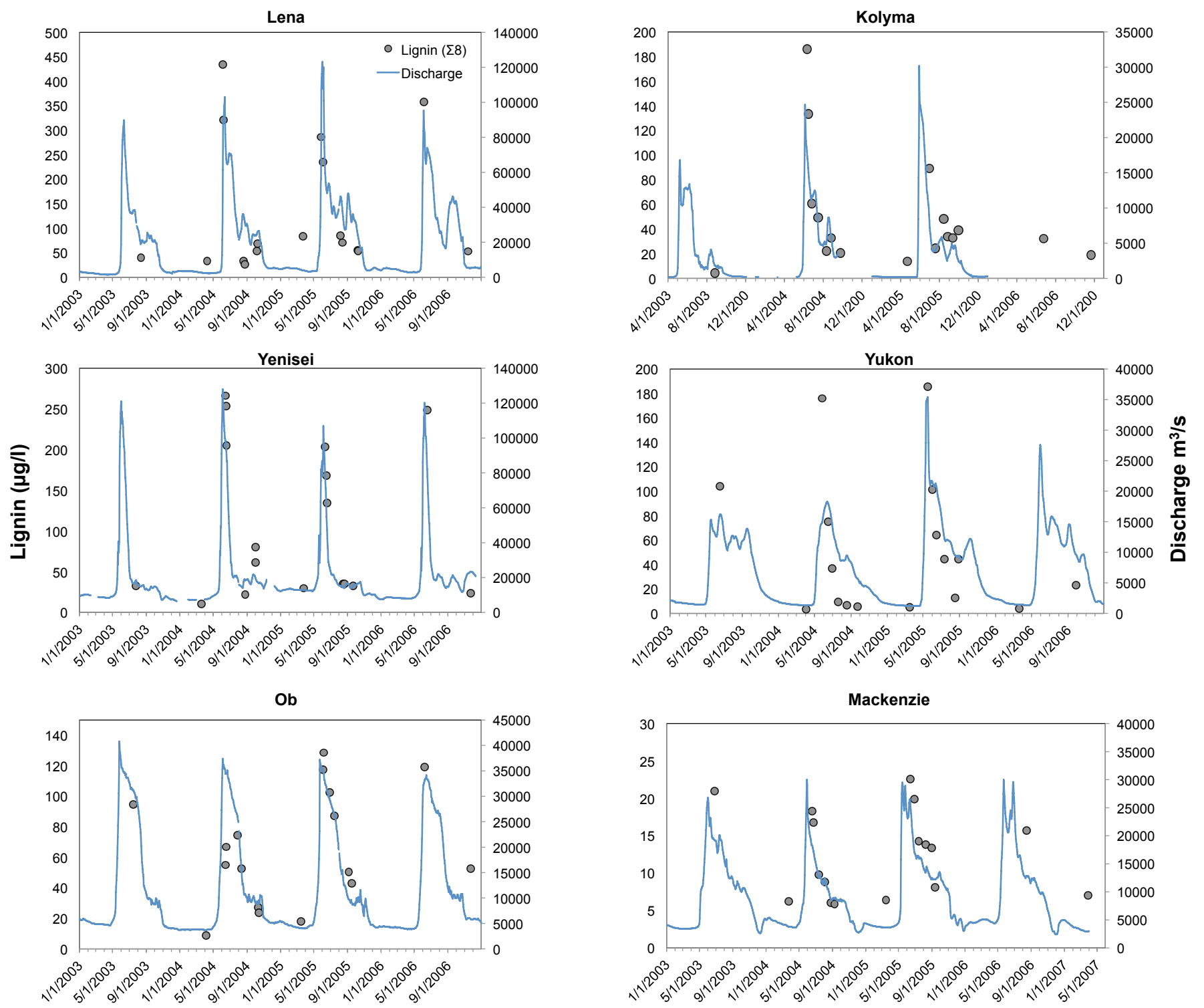

Figure 2 

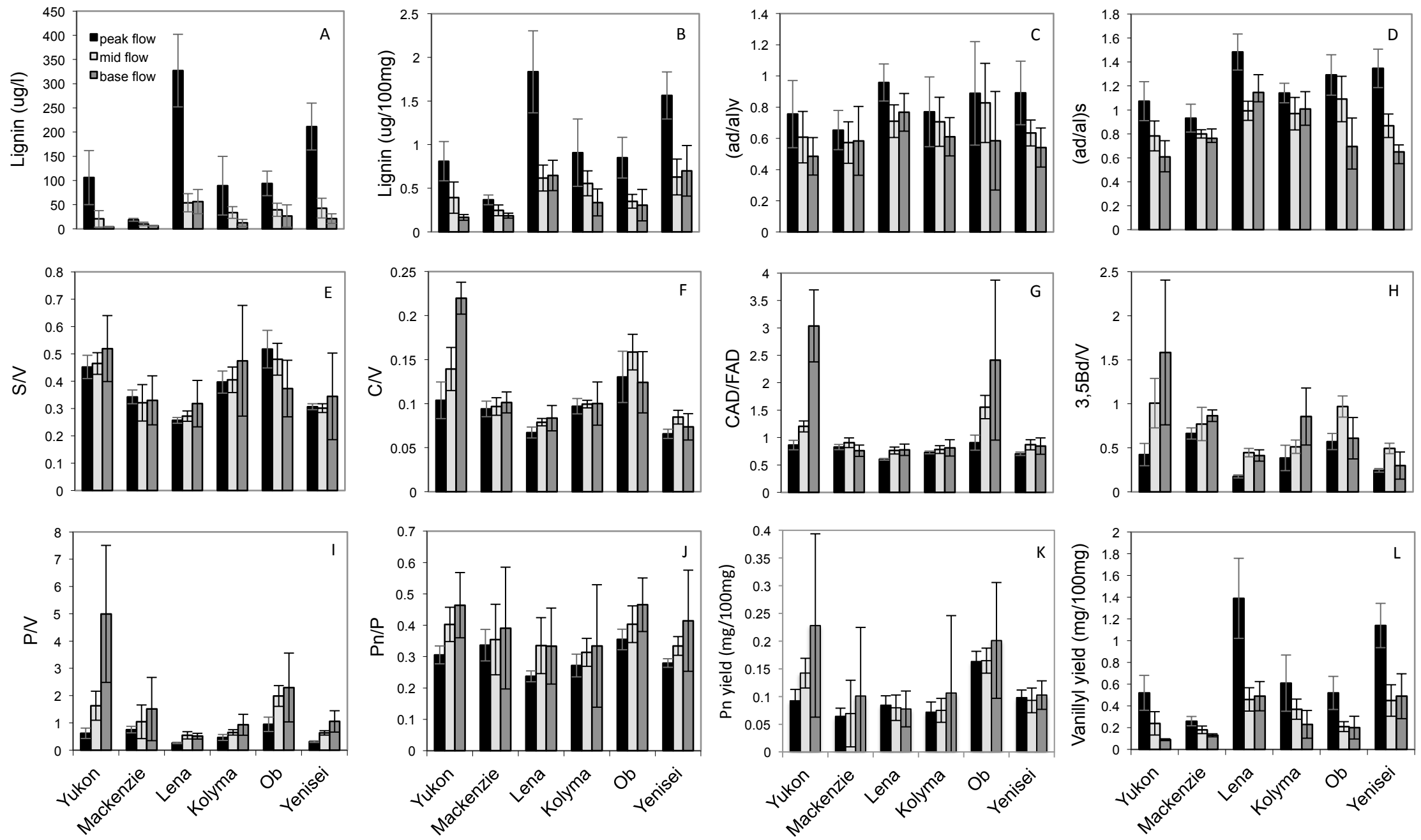

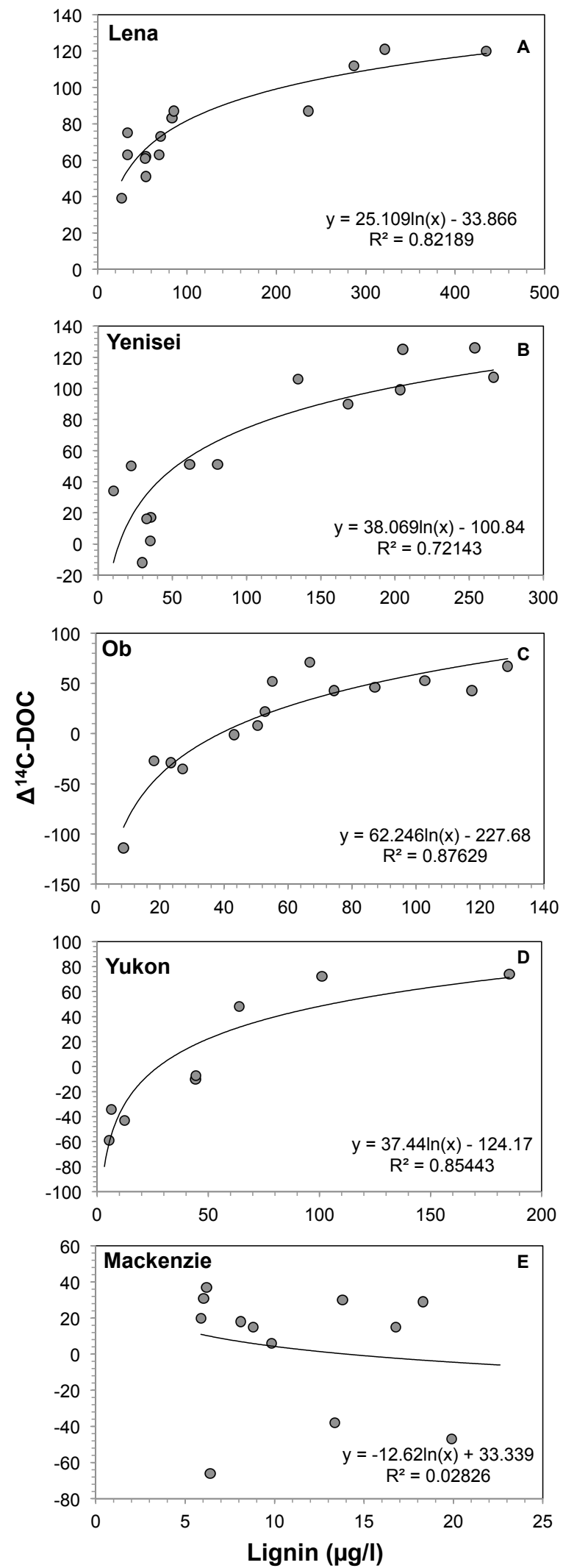

Figure 4 

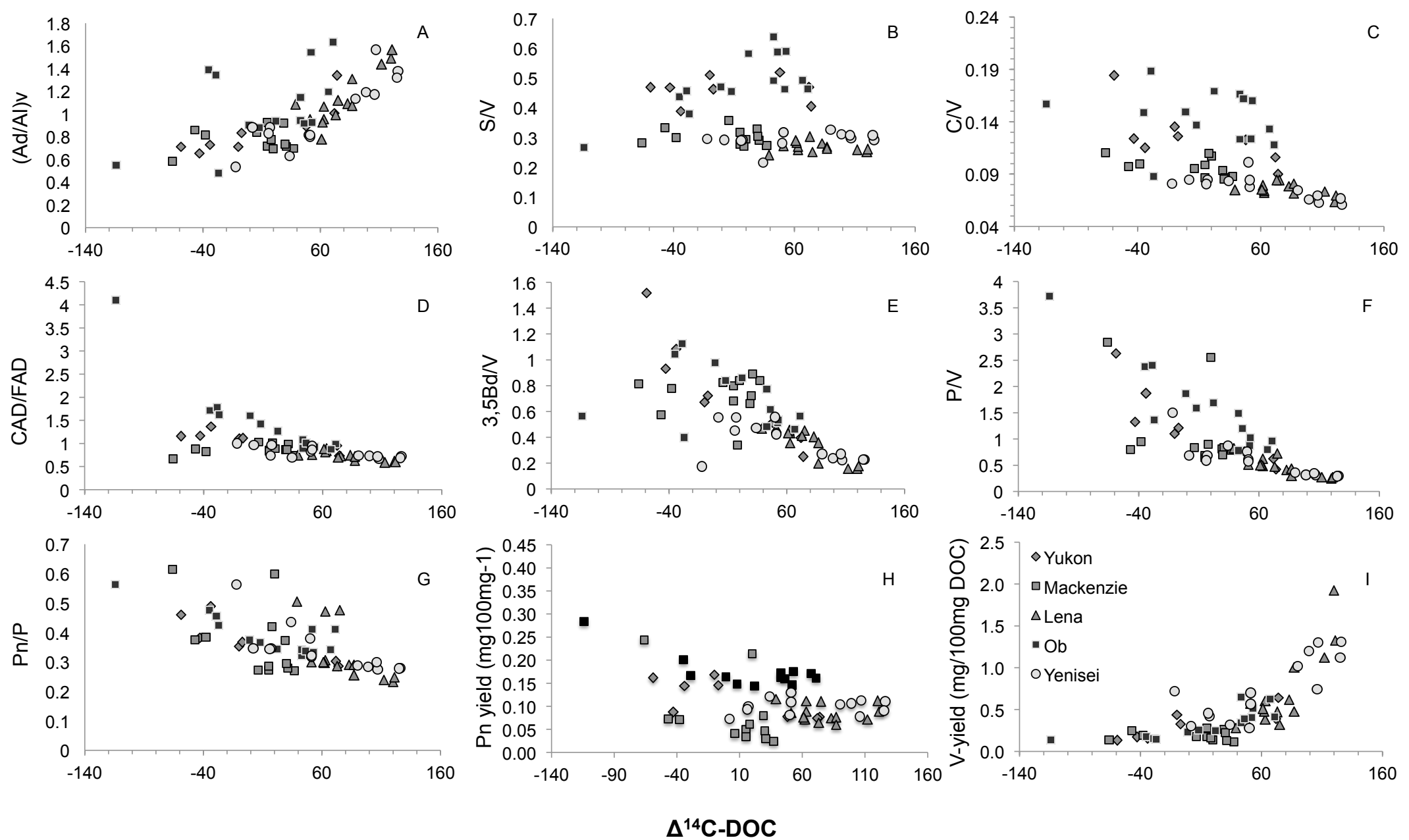

Figure 5 

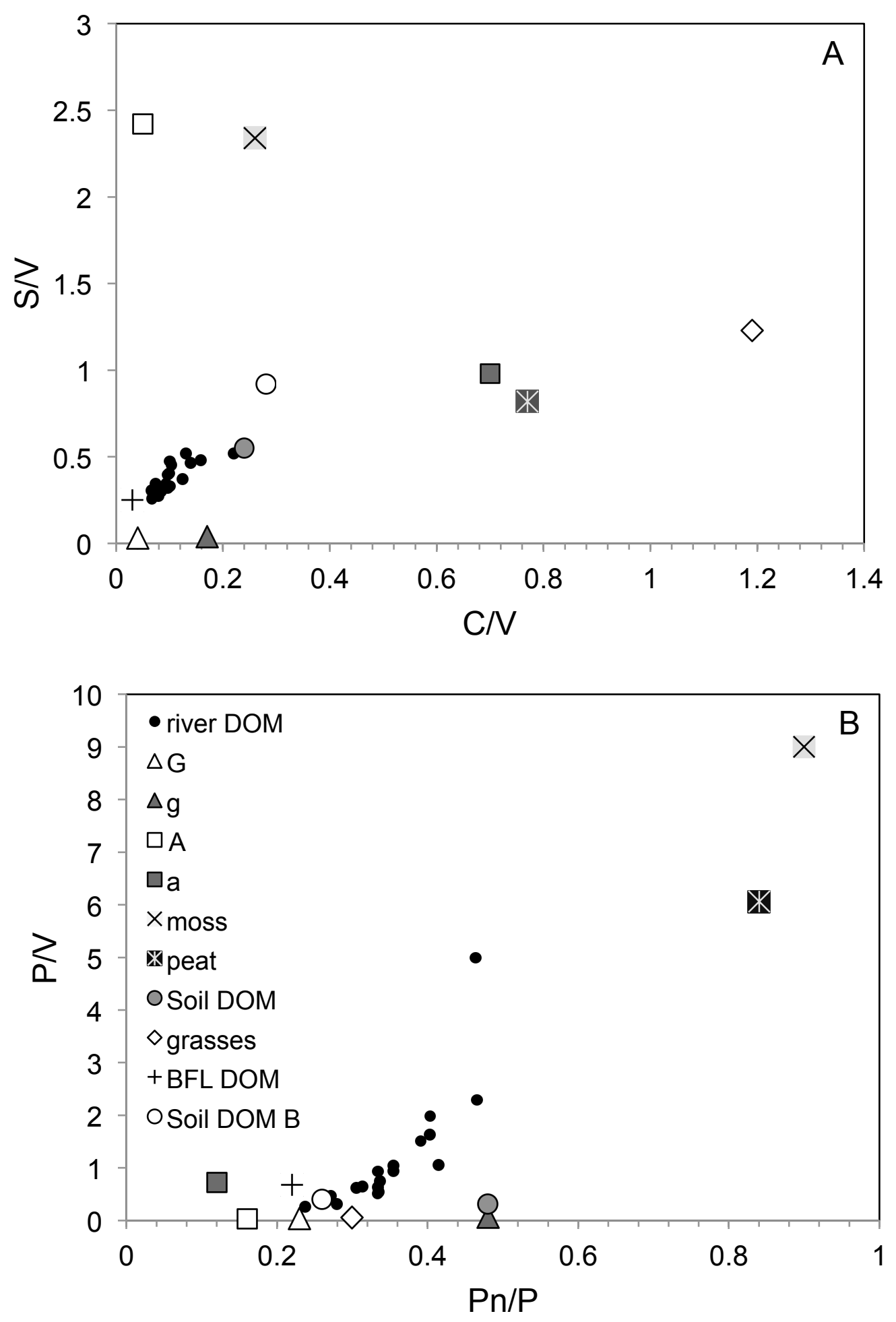

Figure 6 

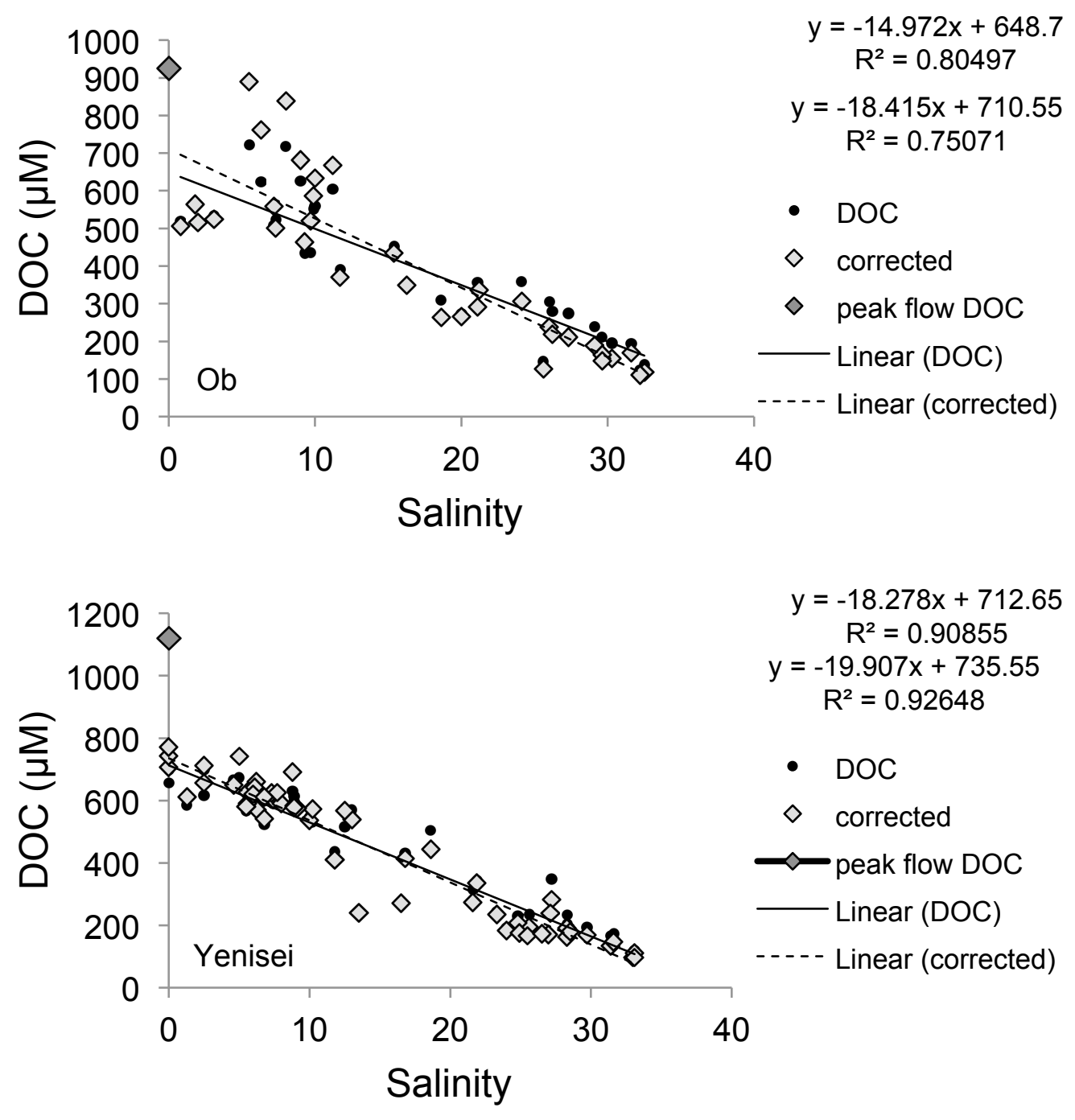

Figure 7 
Table 1. Geographical, climatic and geochemical characteristics of the different river/watershed systems

\begin{tabular}{|l|c|c|c|c|c|c|}
\hline $\begin{array}{l}\text { River and } \begin{array}{l}\text { Watershed } \\
\text { characteristics }\end{array} \\
\text { Discharge }\left(\mathrm{km}^{3} \mathrm{yr}^{-1}\right)_{1}\end{array}$ & Yukon & Mackenzie & Ob & Yenisey & Lena & Kolyma \\
\hline Length $(\mathrm{km})_{1}$ & 2716 & 298 & 427 & 636 & 581 & 111 \\
\hline Catchment $\left(10^{6} \mathrm{~km}^{2}\right)_{1}$ & 0.83 & 1.78 & 2.99 & 2.54 & 2.46 & 0.65 \\
\hline MAAT $\left({ }^{\circ} \mathrm{C}\right)$ & -0.4 & 0.7 & 1.4 & -1.0 & -6.5 & -10.1 \\
\hline Mean slope $\left(\mathrm{m} \mathrm{km}^{-1}\right)$ & 2.93 & 2.23 & 1.28 & 1.94 & 1.83 & 2.16 \\
\hline SPM $\left(10^{6} \mathrm{t} / \mathrm{y}\right)_{2}$ & 60 & 124 & 15.5 & 4.7 & 20.7 & 10.1 \\
\hline Southernmost Lat. $\left({ }^{\circ} \mathrm{N}\right)$ & 58.8 & 52.2 & 45.3 & 45.7 & 52.2 & 60.6 \\
\hline Cont. permafrost $(\%)_{3}$ & 19 & 13 & 1 & 31 & 77 & 99 \\
\hline Deciduous BL forest $(\%)_{3}$ & 0.4 & 1.4 & 10.2 & 3.4 & 1.1 & 0.4 \\
\hline Evergreen NL forest $(\%)_{3}$ & 17.5 & 23.7 & 14.9 & 20.6 & 7.4 & 0.2 \\
\hline Deciduous NL forest $(\%)_{3}$ & 0 & 0 & 1.5 & 32.7 & 58.8 & 49.1 \\
\hline Mixed forest $(\%)_{3}$ & 1.9 & 9.2 & 12.0 & 10.6 & 4.9 & 0.2 \\
\hline Total forest $(\%)_{3}$ & 19.7 & 34.4 & 38.6 & 67.3 & 72.1 & 49.9 \\
\hline Forest $-\mathrm{MODIS}(\%)_{3}$ & 26 & 35 & 25 & 35 & 32 & 10 \\
\hline Shrubland $(\%)_{3}$ & 19.2 & 10.5 & 2.6 & 9.0 & 12.5 & 32.1 \\
\hline Grassland $(\%)_{3}$ & 42.9 & 30.0 & 15.9 & 7.2 & 0.8 & 0.1 \\
\hline Cropland $(\%)_{3}$ & 0.3 & 2.4 & 22.9 & 6.2 & 0.6 & 0 \\
\hline Wetlands $(\%)_{3}$ & 0.4 & 0.1 & 8.5 & 2.6 & 3.3 & 3.8 \\
\hline Water bodies $(\%)_{3}$ & 7.0 & 10.3 & 2.4 & 2.1 & 1.7 & 1.6 \\
\hline
\end{tabular}

${ }^{1}$ Holmes et al. 2011, ${ }_{2}$ Holmes et al. 2002, ${ }^{3}$ We used both Modis vegetation continuous fields (VCF) data and Global Land Cover (GLC) data to generate the vegetation statistics. For reference see: Modis VCF http://glcf.umiacs.umd.edu/data/vcf/ and GLC - http://ies.jrc.ec.europa.eu/global-land-cover-2000

and http://bioval.jrc.ec.europa.eu/products/glc2000/products.php; MAAT = mean annual air temperature, BL $=$ broad leaf, $\mathrm{NL}=$ needle leaf 
Table 2. Mean and discharge-weighted average values for dissolved organic carbon and lignin phenol parameters in the six rivers

\begin{tabular}{|l|c|c|c|c|c|c|}
\hline & Yukon & Mackenzie & Ob & Yenisey & Lena & Kolyma \\
\hline $\mathrm{DOC}(\mathrm{mg} / \mathrm{l})$ & $7.64(7.93)$ & $4.35(4.20)$ & $10.48(8.58)$ & $8.80(8.03)$ & $11.37(11.94)$ & $6.56(7.25)$ \\
\hline$\sum_{8}(\mu \mathrm{g} / \mathrm{l})$ & $52.94(66.64)$ & $12.59(12.70)$ & $66.02(60.94)$ & $108.45(86.17)$ & $134.76(101.87)$ & $49.55(64.17)$ \\
\hline$\Lambda_{8}$ & $0.52(0.55)$ & $0.28(0.20)$ & $0.61(0.53)$ & $1.03(0.77)$ & $0.98(2.14)$ & $0.65(0.77)$ \\
\hline$\sum_{6}(\mu \mathrm{g} / \mathrm{l})$ & $49.42(63.00)$ & $12.07(11.70)$ & $60.67(55.50)$ & $103.08(82.45)$ & $127.67(113.1)$ & $46.30(38.14)$ \\
\hline$\Lambda_{6}$ & $0.49(0.53)$ & $0.27(0.20)$ & $0.56(0.51)$ & $0.97(0.89)$ & $0.93(2.10)$ & $0.6(0.85)$ \\
\hline $\mathrm{S} / \mathrm{V}$ & $0.47(0.48)$ & $0.33(0.3)$ & $0.48(0.58)$ & $0.31(0.31)$ & $0.28(0.28)$ & $0.41(0.38)$ \\
\hline $\mathrm{C} / \mathrm{V}$ & $0.14(0.13)$ & $0.10(0.10)$ & $0.14(0.15)$ & $0.07(0.08)$ & $0.08(0.08)$ & $0.10(0.10)$ \\
\hline $\mathrm{P} / \mathrm{V}$ & $1.81(1.41)$ & $1.02(1.0)$ & $1.49(1.47)$ & $0.58(0.59)$ & $0.46(0.47)$ & $0.63(0.55)$ \\
\hline $\mathrm{Pn} / \mathrm{P}$ & $0.37(0.36)$ & $0.35(0.35)$ & $0.39(0.39)$ & $0.33(0.33)$ & $0.31(0.31)$ & $0.30(0.29)$ \\
\hline $\mathrm{Ad} / \mathrm{Al} l_{\mathrm{v}}$ & $0.87(0.78)$ & $0.84(0.8)$ & $1.13(1.07)$ & $1.03(0.97)$ & $1.16(1.07)$ & $1.03(1.10)$ \\
\hline $\mathrm{Ad} / \mathrm{Al} l_{\mathrm{s}}$ & $0.65(0.38)$ & $0.60(0.60)$ & $0.82(0.79)$ & $0.72(0.69)$ & $0.79(0.77)$ & $0.71(0.56)$ \\
\hline $\mathrm{CAD} / \mathrm{FAD}$ & $1.39(1.24)$ & $0.85(0.9)$ & $1.36(1.35)$ & $0.80(0.82)$ & $0.72(0.73)$ & $0.77(0.75)$ \\
\hline $3,5 \mathrm{Bd} / \mathrm{V}$ & $0.87(1.03)$ & $0.75(0.8)$ & $0.7(0.83)$ & $0.36(0.36)$ & $0.36(0.37)$ & $0.53(0.45)$ \\
\hline$\Lambda_{\mathrm{Pn}}$ & $0.14(0.13)$ & $0.07(0.12)$ & $0.18(0.18)$ & $0.1(0.08)$ & $0.08(0.08)$ & $0.08(0.07)$ \\
\hline$\Lambda_{\mathrm{V}}$ & $0.33(0.31)$ & $0.2(0.2)$ & $0.37(0.34)$ & $0.74(0.64)$ & $0.73(0.50)$ & $0.43(0.58)$ \\
\hline
\end{tabular}

Concentration of lignin is given as the sum of 8 lignin phenols $\left(\sum_{8} ; \mathrm{V}, \mathrm{S}, \mathrm{C}\right)$ and the sum of 6 lignin phenols $\left(\sum 6 ; \mathrm{V}\right.$ and $\mathrm{S}$ ). Yields ( $\Lambda$-values) are given in $\mathrm{mg} 100 \mathrm{mg}^{-1} \mathrm{DOC}$ and reflect the concentration of the 8 or 6 lignin phenols normalized to DOC concentrations. 
Table 3. Total annual discharge of dissolved organic carbon and lignin phenols from the six rivers along with their relative contributions.

\begin{tabular}{|l|c|c|c|c|c|c|c|}
\hline & Yukon & Mackenzie & Ob & Yenisei & Lena & Kolyma & $\begin{array}{c}\text { Annual } \\
\text { load }\end{array}$ \\
\hline DOC $\left(\mathrm{Tg} \mathrm{yr}^{-1}\right)$ & 1.75 & 1.20 & 3.04 & 5.08 & 6.47 & 0.71 & 18.25 \\
\hline \% total DOC & 9.60 & 6.60 & 16.70 & 27.80 & 35.50 & 3.90 & 100.00 \\
\hline Lignin $\left(\mathrm{Gg} \mathrm{yr}^{-1}\right)$ & 14.70 & 3.60 & 21.50 & 54.30 & 91.60 & 6.16 & 192.00 \\
\hline \% total Lignin & 7.70 & 1.90 & 11.20 & 28.30 & 47.70 & 3.20 & 100.00 \\
\hline \% freshet lignin* & 64 & 49 & 66 & 78 & 78 & 78 & \\
\hline
\end{tabular}

*freshet lignin was calculated for the months May and June by multiplying the average daily discharge of these months with the average lignin concentrations measured during May and June and upscaling to 61 days. Discharge volumes were not necessarily highest in May, but the concentration of lignin phenols was always highest in the very early phase of freshet. 
Table 4. Lignin phenol parameters in different source material and aquatic environments

\begin{tabular}{|c|c|c|c|c|c|c|c|c|}
\hline & $\mathrm{Ad} / \mathrm{Al}_{\mathrm{v}}$ & $\mathrm{S} / \mathrm{V}$ & $\mathrm{C} / \mathrm{V}$ & $\mathrm{P} / \mathrm{V}$ & $\mathrm{Pn} / \mathrm{P}$ & $\Lambda_{\mathrm{Pn}}$ & CAD/FAD & $\Lambda_{\mathrm{V}}$ \\
\hline Gym. Wood $_{1,2,3}$ & 0.19 & 0.03 & 0.04 & 0.04 & 0.23 & 0.05 & 0.11 & 10 \\
\hline Gym. Needles $1,2,3,5$ & 0.32 & 0.04 & 0.17 & 0.07 & 0.47 & 0.29 & 3.18 & 7.2 \\
\hline Ang. Wood $1,2,3$ & 0.15 & 2.42 & 0.05 & 0.03 & 0.16 & 0.01 & 0.19 & 3.34 \\
\hline Ang. Leaves ${ }_{1,2,3}$ & 0.24 & 0.98 & 0.7 & 0.72 & 0.12 & 0.04 & 8.7 & 1.06 \\
\hline Grasses $_{3}$ & 0.19 & 1.23 & 1.19 & 0.06 & 0.3 & 0.05 & 0.43 & 2.7 \\
\hline Moss $_{3}$ & 0.82 & 2.34 & 0.26 & 9.0 & 0.9 & 2.38 & 2.83 & 0.23 \\
\hline Wetland plants ${ }_{5}$ & 0.22 & 1.9 & 3.05 & 0.5 & 0.22 & - & 5.53 & - \\
\hline Peat (sphagnum sp.) 3 & 0.27 & 0.82 & 0.77 & 6.06 & 0.84 & 1.41 & 0.66 & 0.3 \\
\hline Peat $_{5}$ & 0.34 & 0.82 & 0.88 & 1.49 & 0.44 & 0.36 & 0.74 & 1.13 \\
\hline Boreal forest soil-org. $\mathrm{h}_{.4}$ & 0.42 & 0.24 & 0.42 & 0.22 & 0.30 & - & 0.63 & 1.05 \\
\hline Boreal forest soil-inorg. h.4 & 1.65 & 0.11 & 1.18 & 0.81 & 0.20 & - & 3.82 & 0.28 \\
\hline Boreal forest soil 13 & 2.25 & 0.29 & 0.18 & - & - & - & 0.56 & 0.88 \\
\hline Boreal forest soil $_{3}$ & 0.49 & 0.45 & 0.27 & - & - & - & - & - \\
\hline Alpine Tundra soil 13 & 2.05 & 0.56 & 0.46 & - & - & - & 0.80 & 0.36 \\
\hline DOM soil $_{3}$ & 1.15 & 0.55 & 0.24 & 0.31 & 0.48 & 0.04 & 0.79 & 0.78 \\
\hline DOM-alpine bog 6 & 0.91 & 0.80 & 0.18 & 1.44 & - & - & 1.5 & - \\
\hline DOM- needles leachate ${ }_{7 \text { (Picea sp.) }}$ & 0.49 & 0.02 & 0.23 & - & - & - & - & 0.95 \\
\hline DOM- twigs leachate 7 (Picea sp.) & 1.31 & 0.16 & 0.14 & - & - & - & - & 0.90 \\
\hline DOM- leaves leachate $_{7}$ (Betula sp.) & 0.52 & 0.73 & 0.42 & - & - & - & - & 0.66 \\
\hline DOM-grass leachate $_{7}$ & 0.87 & 1.93 & 1.11 & - & - & - & - & 0.8 \\
\hline DOM-sphagnum leachate $_{7}$ & 1.55 & 0.95 & 1.15 & - & - & - & - & 0.01 \\
\hline DOM (tundra rivers) 8 & 1.32 & 0.70 & 0.46 & - & - & - & - & - \\
\hline DOM (boreal lakes) $_{9}$ & 1.01 & 0.25 & 0.03 & 0.68 & 0.22 & 0.04 & - & 3.23 \\
\hline DOM (Amazon river) ${ }_{10}$ & 1.66 & 0.54 & 0.10 & 0.66 & - & - & - & 0.77 \\
\hline DOM (Mississippi river) 11 & 0.88 & 0.80 & 0.15 & - & - & - & - & 0.14 \\
\hline DOM (Broad river) 12 & 1.74 & 0.57 & 0.09 & 0.44 & 0.25 & 0.02 & 0.88 & 0.2 \\
\hline
\end{tabular}

1-Hedges and Mann (1979); 2-Hedges and Parker, 3-Prokushkin et al, in prep, 4-Houel et al. (2006); 5-Williams et al (1998); 6-Ertel et al. (1993); 7-Spencer et al. (2008); 8-Lobbes et al. (2000); 9-Ouellet et al. (2009); 10-Ertel et al.(1986) and Hedges et al. (2000); 11-Opsahl and Benner (1998); 12-Benner and Kaiser (2010), 13-Ugolini et al 1981. Yields $(\Lambda)$ are given in $\mathrm{mg} 100 \mathrm{mg}^{-1} \mathrm{DOC}$ 